Western University Scholarship@Western

Law Publications

Law School

2012

\title{
Fairness in International Economic Law and Relations
}

Chios Carmody

The University of Western Ontario

Follow this and additional works at: https://ir.lib.uwo.ca/lawpub

Part of the International Trade Law Commons

Citation of this paper:

Carmody, Chios, "Fairness in International Economic Law and Relations" (2012). Law Publications. 175.

https://ir.lib.uwo.ca/lawpub/175 


\title{
FAIRNESS IN INTERNATIONAL ECONOMIC LAW AND RELATIONS
}

\author{
By Chios Carmody \\ Associate Professor \& Canadian National Director \\ Canada-United States Law Institute \\ Faculty of Law \\ University of Western Ontario \\ London, Ontario, Canada N6A 3K7 \\ email: ccarmody@uwo.ca
}

October 14, 2012

\section{Draft - not to be reproduced or cited without author's permission.}

\begin{abstract}
The idea of fairness is a recurrent one in international economic law and relations. By and large, however, commentators have failed to provide a structured understanding for this vital concept or explain its reflection in legal rules. This article proposes a theory of fairness as part of a broader theory of justice, suggesting that fairness is a part of justice, but not the whole of it. Rather, justice may be thought of as a combination of equality plus fairness (i.e. justice $=$ equality + fairness), with the proviso that in any complex system of legal rules, equality must be greater than, or conceptually prior to, fairness (i.e. equality > fairness). Equality and fairness together constitute a "nested opposition" that legal rules constantly oscillate between. In the latter half of this article a look is taken at how these conceptual relationships are expressed in three regimes of international economic law: investment, trade and monetary affairs.
\end{abstract}




\title{
FAIRNESS IN INTERNATIONAL ECONOMIC LAW AND RELATIONS
}

\author{
By Chios Carmody ${ }^{1}$
}

\author{
1. Introduction \\ 2. The Concept and Role of Fairness \\ 3. Fairness in International Economic Law \\ a. Fairness in International Investment Law \\ b. Fairness in International Trade Law \\ c. Fairness in International Monetary Law \\ 4. Some Concluding Thoughts
}

\section{Introduction}

*. What is fair and what role does fairness play in human affairs? These are substantial questions, questions of perennial concern. We often say that something is "fair" in the sense of it being fitting or appropriate, but how this idea is to be distinguished from other proximate ideas like equality or justice is unclear. ${ }^{2}$ Moreover, there seems to be an innate sense among human beings that the social arrangements and communities we live in should be "fair", but again, what this aspiration means and how it is to be reconciled with the notions of fittingness or appropriateness mentioned above are uncertain.

*. A very visible manifestation of these sentiments occurred in the fall of 2011 when protests organized under the banner of the Occupy Movement erupted in cities across the United States and around the world. ${ }^{3}$ The protesters' demands were many and varied, but in the main they centered on the growth of income and social inequality during a time of uneven economic performance and intensifying competition. In one way or another, the protesters' demands raised the issue of fairness. Is it fair for a small minority of the population in many countries to reap the benefits of recent economic growth? ${ }^{4}$ Have continuing waves of privatization - of schools, utilities and other regulated institutions - created "pools of privilege" that impede social mobility? So immediate and compelling are these questions that at least one candidate for the U.S. presidency in 2012 has made fairness a central plank of his platform. ${ }^{5}$

*. Yet domestic politics and law are not the only venues for fairness queries and claims. Issues of fairness are constantly being raised in international law, and in international economic relations in

\footnotetext{
${ }^{1}$ Associate Professor \& Canadian National Director, Canada-United States Law Institute, Faculty of Law, University of Western Ontario, London, Ontario, Canada N6A 3K7. email: ccarmody@uwo.ca.

2 "Fair ... [f]ree from bias, fraud or injustice; equitable, legitimate." J.A. Simpson \& E.S.C. Weiner, The Oxford English Dictionary Vol. $V\left(2^{\text {nd }}\right.$ ed.) 671 (1989). Legal dictionaries offer a slightly different definitions. "Fair means ... 1. impartial; just; equitable; disinterested; 2. Free from bias or prejudice ...". Blacks Law Dictionary ( $9^{\text {th }}$ ed.) 674 (Brian Garner, ed.); "Fair means ... reasonable", Daphne Dukelow, The Dictionary of Canadian Law (4 ${ }^{\text {th }}$ ed.) 474 (2011).

${ }^{3}$ For a summary of the Movement's themes and views see Janet Byrne (ed.), The Occupy Handbook (2012).

${ }^{4}$ In the United States, for instance, incomes of the top 1 percent of income earners grew 3.9 percent a year, capturing more than half of the overall economic growth experienced between 1993 and 2008. See Facundo Alvaredo, "Inequality over the Past Century", 48:3 Finance \& Development 28 (Sept. 2011). The Economist has observed, “... within many countries income gaps have widened. More than two-third of the world's people live in countries where income disparities have arisen since 1980, often to a startling degree. In America the share of national income going to the top $0.01 \%$ (some 16,000 families) has risen from just over $1 \%$ in 1980 to almost $5 \%$ now - an even bigger slice than the top 0.01\% got in the Gilded Age." "True Progressivism" 405 The Economist 8806 p. 13 (October $13,2012)$.

${ }^{5}$ See The White House, "Remarks on the Economy in Osawatomie, Kansas" (Dec. 6, 2011). For commentary see "The Election: The President Chooses his Ground" 950 The Economist (Dec. 10, 2011). Similar comments were made in the 2012 State of the Union Address where U.S. President Barack Obama mentioned "the basic American promise that if you worked hard, you could do well enough to raise a family, own a home, send your kids to college, and put a little away for retirement. ... The defining issue of our time is how to keep that promise alive ... We can either settle for a country where a shrinking number of people do really well while a growing number of Americans barely get by, or we can restore an economy where everyone gets a fair shot, and everyone does their fair share, and everyone plays by the same set of rules." The White House, "The State of the Union Address" (Jan. 24, 2012) (emphasis added).
} 
particular. During the 1960s, for instance, a "New International Economic Order" (NIEO) became a rallying cry for developing country governments and people who sought a more equitable division of the world's resources, industry and wealth. The principal point of their advocacy was the perception that the then emerging system of global capitalism was unfair. ${ }^{6}$ Likewise, during the 1980s and 1990s a number of governments and commentators criticized the "Washington Consensus", a set of policy prescriptions on privatization, debt reduction and public sector restraint. ${ }^{7}$ A key complaint was that the prescriptions were unrealistic and unfair. And in the late 2000s several Latin American countries withdrew from the compulsory jurisdiction of the International Centre for the Settlement of Investment Disputes (ICSID), voicing the common concern that ICSID procedures for investment arbitration were one-sided and unfair. ${ }^{8}$

*. Despite these claims, the question of the content of fairness and what role it plays in communal arrangements remains surprisingly open. Apart from underlying themes of inequality and subjectivity, few of the fairness claims outlined above appear to involve a common definition of the concept. Fairness seems to be mostly an intuitive matter: we know it when we see it. Not surprisingly, thinking about fairness in both international law and international economic law remains muddled and confused. ${ }^{9}$

*. In 1995, for instance, Thomas Franck proposed that the central question in international law is whether or not international law is fair. ${ }^{10}$ Franck advanced this question without explaining why, as a preliminary matter, fairness, as opposed to equality or justice or any other value ordinarily spoken about in connection with international law, should merit pre-eminent consideration. After all, the traditional inquiry in law is not fairness, but justice, as is implicit from the appellation of the preeminent tribunal of international law, the International Court of Justice. Similarly, in 2000 Steven Suranovic observed that "[t]he literature on fairness is diverse, multi-disciplinary, and often impenetrable", but then seemed to add to that impenetrability by positing several different types of

\footnotetext{
${ }^{6}$ Alexandra Diehl observes that "a new form of equity doctrine evolved when developing countries started to demand an NIEO. The call for this new economic order ... took explicit form in three 1974 United Nations General Assembly resolutions which all contain references to equity ... [The resolutions] all reflect[] a common understanding to define equity as a form of distributive justice - in other words an element of fairness." Alexandra Diehl, The Core Standard of International Investment Protection: Fair and Equitable Treatment, pp. 318-319 (2012).

${ }^{7}$ The term Washington Consensus was coined in 1989 to describe a set of ten relatively specific economic policy prescriptions that he considered constituted the "standard" reform package promoted for crisis-wracked developing countries during the 1980s by Washington, D.C.-based institutions such as the International Monetary Fund, the World Bank and the U.S. Treasury Department. The prescriptions encompassed policies in such areas as macroeconomic stabilization, economic opening with respect to both trade and investment, and the expansion of market forces within the domestic economy. The term Washington Consensus has come to be used fairly widely in a second, broader sense, to refer to a more general orientation towards a strongly market-based approach to economic development.

${ }^{8}$ When the number of ICSID investment claims began to grow during the late 1990s, concern about the fairness and integrity of ICSID's dispute settlement system began to increase. In May 2007 Bolivia withdrew from the Washington Convention and was followed by Ecuador in July 2009. In addition, in 2008 the Venezuelan Supreme Court issued an opinion limiting the extent of the country's consent to submit to ICSID jurisdiction. All of the announcements of withdrawal or modification of consent echo traditional criticisms of the investor-state system of protection, but they can also be linked to recent waves of nationalization and expropriation undertaken in the region. Arguments raised by Latin American governments against ICSID are generally that ICSID awards are not subject to appeal, that the majority of ICSID disputes have been decided in favour of investors and therefore betray a lack of neutrality and impartiality, that claims under the treaty can only be launched by private investors (as opposed to states), and that the cost of arbitration is high. Debate now centers on the legal effect of the withdrawals: see Ignacio Vincentelli, "The Uncertain Future of ICSID in Latin America", Electronic copy available at http://ssrn.com/abstract=1348016 (2008); Antonios Tzanakopoulos, "Denunciation of the ICSID Convention under the General International Law of Treaties", Electronic copy available at http://ssrn.com/abstract=1735495 (2010) reprinted in Rainer Hofmann \& Christian Tams (eds), International Investment Law and General International Law 75 (2011).

${ }^{9}$ For an index of recent literature on fairness see Andrew Brown \& Robert Stern, "Concepts of Fairness in the Global Trading System" 12:3 Pacific Econ. Rev. 293, 318 (2007). See also Nicholas Rescher, Fairness: theory and practice of distributive justice (2002).

${ }^{10}$ Franck observed, "Like any maturing legal system, international law has entered into its post-ontological era ... The questions to which the international lawyer must now be prepared to respond to ... are different from the traditional inquiry: whether international law is law. Instead, we are now asked: is international law effective? Is it enforceable? Is it understood? And, the most important question: Is international law fair?" Thomas Franck, Fairness in International Law and Institutions 6 (1995). Many commentators subsequently picked up on this theme of fairness identified by Franck. For a critical appraisal see John Tasioulas, "International Law and the Limits of Fairness" 13:4 Eur. J. Int'l L. 993 (2002).
} 
fairness. ${ }^{11}$ Suranovic concluded that while his scheme of classification helped to identify "the fundamental basis for normative arguments", the inherent subjectivity of fairness meant "reasonable fairness principles will conflict when applied to a particular policy action", leading to what he termed "a kind of 'impossibility theorem' ... that there is no way to determine a set of objectively fair principles." ${ }^{2}$ Likewise in 2006 Amrita Narlikar, writing about the fairness of international trade relations conducted under the auspices of the World Trade Organization (WTO), interpreted fairness to mean legitimacy of process and equity of outcomes and noted that there have been shifts in the attitudes of developing countries towards the institutional balance struck between these two concepts in the organization. ${ }^{13}$ Like Franck however, she did not explain why fairness is important as a substantive matter nor why it might be of concern to developing countries in the WTO. And in a contribution on the same subject by Andrew Brown and Robert Stern published in 2007, the authors concluded with the cautionary observation that "[a]ny attempt to define fairness in global trade relations should teach humility" and that "there is still no conclusive and incontrovertible way of assessing fairness." 14

*. These many contributions and the myriad ways in which they approach the subject should demonstrate that there remains considerable uncertainty and confusion about the content and role of fairness. To develop a more systematic understanding, we appear to need a theory. A theory is a "system of ideas"15, with the emphasis being on the "system", or set of relationships, regularly exhibited between those ideas. ${ }^{16}$

*. In this article I develop a theory of fairness as part of a larger theory of justice. I suggest that fairness is a part of justice, but not the whole of it. Instead, drawing on recent insights from biology and evolutionary psychology, I suggest that rules about fairness in international economic law are a reflection of the fact that fairness is important to the formation of groups. A commitment to fairness is a community's pledge that the community will be attentive to an individual's particular concerns, needs or wants. ${ }^{17}$ In effect, the pledge is one of 'appropriateness' that helps to secure an individual's participation in communal arrangements. Biologists and evolutionary psychologists have inferred from this that the pledge facilitates the division of labour and therefore contributes to the tremendous degree of sophistication observed in today's global economy. ${ }^{18}$

*. From this hypothesis I go on to suggest that we are chiefly interested in fairness as an indicator of relationships, relationships that, because of humans' propensity towards interdependence, tend to promote the creation of the complex communities we live in and also allow for the remarkable feats of cooperation that occur within them such as organ donor schemes, futures markets and the internet. ${ }^{19}$

\footnotetext{
${ }^{11}$ Suranovic identifes three types of equality fairness (non-discrimination fairness, distributional fairness, Golden-Rule fairness) and four types of reciprocity fairness (positive reciprocity fairness, negative reciprocity fairness, privacy fairness and maximum benefit fairness). However, he observes that "The concept itself overlaps with many other normative principles such as justice, equity, law and even morality. As such, one cannot simply pick up a book or article and quickly discover what fairness means or how to distinguish between the various normative principles. And yet, at the same time, everyone seems to have an inherent sense of what fairness is." Steven Suranovic, "A Positive Analysis of Fairness with Applications to International Trade" 23:3 The World Economy $283(2000)$.

${ }^{12}$ Ibid., pp. 304-306.

${ }^{13}$ Amrita Narlikar, "Fairness in International Trade Negotiations" 29 The World Economy 1005 (2006).

${ }^{14}$ See supra, note 9,316 (2007).

${ }^{15}$ S.v. "Theory”, Shorter Oxford English Dictionary (5 ${ }^{\text {th }}$ ed.) 3236 (2002).

${ }^{16}$ For a treatment of systems and systems theory see Donella Meadows, Thinking in Systems (2008). For an attempt to define the elements of a legal system see Joseph Raz, The Concept of a Legal System (1980).

${ }^{17}$ This is my abstraction of Joseph Henrich's definition of fairness as "whatever combination of motivations and expectations yields more equal divisions." Joseph Henrich et al., "Markets, Religion, Community Size, and the Evolution of Fairness and Punishment", 327 Science 1483 (19 March 2010) (emphasis added).

18 "The efficiency of market exchange involving infrequent or anonymous interactions improves with an increasingly shared set of motivations and expectations related to trust, fairness and cooperation." Ibid. at 1480 (emphasis added).

19 "Although frequent and efficient exchanges among strangers are now commonplace, studies of nonhuman primates and small-scale societies suggest that during most of our evolutionary history, transactions beyond the local group, and certainly beyond the ethnolinguistic unit, were fraught with danger, mistrust, and exploitation. Thus, we propose that such "market norms" may have evolved as part of an overall process of societal evolution to sustain mutually beneficial exchanges in contexts where established social relationships (for example, kin, reciprocity, and status) were insufficient. If our theory is correct, then measures of fairness in
} 
Fairness can be thought of as the minimum 'price' for such relationships to be sustained.

*. At the same time, however, fairness is not everything. I further suggest that while traditional communities are heavily fairness-oriented, as they become larger and more complex, they search for a new metric appropriate to the growth of impersonal transactions, or in other words, transactions in which no continuing relationship is assumed. This comes about in the form of equality.

*. Equality has long been the abstract ideal of a political community, but in modern life it assumes enhanced importance because individuals engage in episodic transactions with strangers to meet most of their daily needs. ${ }^{20}$ This impersonality, in turn, feeds a preoccupation in legal rules with the attainment of equality. However, the preoccupation can only be partly fulfilled since each instance of doing equality involves the impossible task of assessing identity and constitutes, in essence, a single instance of 'fairness'. ${ }^{21}$

*. Considered carefully, therefore, equality is largely an idealistic and aspirational value, one that contrasts with the realism and pragmatism of fairness. As we will see, equality and fairness constitute "nested oppositions" to each other, "that is, oppositions which also involve a relation of dependence, similarity, or containment between the opposed concepts." 22 Whereas equality is general, absolute and plenary, fairness is relational, conditional and exceptional. We can think of them and their associated characteristics as polarities between which the law constantly oscillates. The structure of legal rules in several different fields of international economic relations tends to bear this basic opposition out.

*. Following this Introduction, therefore, Part 2 more fully develops a theory of fairness as part of a larger communitarian theory of justice. Part 3 goes on to examine how these ideas are exhibited and confirmed by practice in three different fields of international economic law - investment, trade and monetary affairs. Fairness considerations are a reflection of the particular 'community', or set of relationships, created under law in each field. Part 4 provides some concluding remarks about the relevance of fairness for international economic relations.

\section{The Concept and Role of Fairness}

*. The idea of fairness is elusive. As Americo Beviglia Zampetti observed in 2006:

Fairness is a complex idea with a long history. As Woods put it, 'very few ideas are very new', and fairness is certainly not one of them. There is no accepted, uniform, and commonly shared definition of fairness. The notion is strongly associated with such ideas as equality, proportionality, reciprocity, equity, and justice, only to mention other terms that have found currency in the trade policy discourse. These concepts are entangled and their usage across disciplines and policy areas is far from univocal. But fairness, like justice, addresses issues that are fundamental to the social life of individuals as well as to nations. ${ }^{23}$

situations lacking relationship information (for example, anonymous others) should positively covary with market integration." Ibid.

${ }^{20}$ Paul Seabright has written: "Homo sapiens sapiens is the only animal that engages in elaborate task-sharing - the division of labour as it is sometimes known - between genetically unrelated members of the same species. It is a phenomenon as remarkable and uniquely human as language itself. Most human beings now obtain a large share of the provision of their daily lives from others to whom they are not related by blood or marriage." Paul Seabright, The Company of Strangers 1 (2004).

${ }^{21}$ This phenomenon of justice-as-fairness, or in other words, of justice conceived of as the doing of individual instances of fairness, is observed in transactional situations where "the marketplace balances out the various subjective perspectives of value by a large number of buyers and sellers." In the process, subjective instances of value are 'objectivized'. For mention of these ideas in connection with international investment law see Irmgard Marboe, Calculation of Compensation and Damages in International Investment Law, pp. 24-25 (2009).

${ }^{22}$ Jack Balkin, "Nested Oppositions", 99 Yale L.J. 1669 (1990). Balkin went on to explain that a nested opposition is "a resituation of the opposition that allows us to see both difference and similarity, both conceptual distinction and conceptual dependence." Ibid. at 1671 .

${ }^{23}$ Americo Bevigilia Zampetti, Fairness in the World Economy 26 (2006). Similarly, Steven Suranovic has written, "The concept itself overlaps with many other normative principles such as justice, equity, law and even morality. As such, one cannot simply pick 
A similar lack of clarity about the definition of fairness is observed in international economic relations. Commentators often fail to provide a definition or simply assume its importance without explaining why it might be so fundamental. Given these qualifications, it is useful at the outset to examine the concept and role of fairness.

*. In common English usage what is "fair" is considered to be fitting or appropriate to the circumstances. ${ }^{24} \mathrm{We}$ say, for example, that a particular transaction is fair, meaning that it is suitable for all concerned. This is not, however, the same as saying that it is economically optimal. A fair transaction will simply be unobjectionable.

*. This set of preliminary observations provides some initial insight about the content of fairness. First, fairness is a rough measure of what is socially acceptable. It may not satisfy every interest fully, but it is enough to preserve the relationships involved. Second, the use of fairness suggests that it is something which applies in particular situations as contrasted with general ones. Fairness is something that humans are chiefly concerned with as an attribute of their continuing relationships. Instinct tells us that it would make a poor rule for human behaviour as a whole. Third, fairness is not equality (i.e. fairness $\neq$ equality). The plain difference in terminology emphasizes the fact that there is a clear distinction between the two concepts. ${ }^{25}$ Instead, fairness can be thought of as inequality, although as we will see, it is inequality of a special type.

*. These preliminary observations invite controversy and need to be tested against a range of usages and practice in order to be confirmed. Research results from science can help. Since 2000 there has been considerable scientific research into the origins and nature of fairness. ${ }^{26}$ Both biologists and evolutionary psychologists have sought to determine the origins and contribution of fairness to human relations.

*. The research reveals that fairness is a uniquely human trait. It is something that is not observed in our closest genetic relative, the chimpanzee. ${ }^{27}$ Looking at the way species have evolved differently, biologists and evolutionary psychologists have hypothesized that fairness is vital to human interaction, and in particular, to the formation of groups. These are not just small-scale groups, such as families, kinship assemblies and associations, where individuals are likely to know each other intimately and where, in particular, they are likely to discount or revalue their transactions in the expectation of a continuing relationship, but also include larger, more complex forms of human affiliation where personal connections are effectively lost and where, as Joseph Henrich has recently pointed out, substitutive social mechanisms such as religion, education and esteem for altruistic behaviour all contribute to reinforce the wider communal sense of fairness. ${ }^{28}$

up a book or article and quickly discover what fairness means or how to distinguish between the various normative principles. And yet, at the same time, everyone seems to have an inherent sense of what fairness is." Steven Suranovic, "A Positive Analysis of Fairness with Applications to International Trade" 23(3) The World Economy 283 (2000).

${ }^{24}$ See definitions provided supra, note 2 .

${ }^{25}$ Confirmation of this point comes from common definitions, which do not always equate fairness with equality. Instead, they tend to suggest that fairness plays a supplementary role in attaining equality. For example, Ioana Tudor observes, "the common understanding given to fair treatment is that of right and reasonable treatment that sometimes may achieve equality between the parties, although this is not always the case." Ioana Tudor, The Fair and Equitable Treatment Standard in the International Law of Foreign Investment 126 (2008) (emphasis added). Joseph Henrich refers to behavioural fairness as "whatever combination of motivations and expectations yields more equal divisions". Joseph Henrich et al., "Markets, Religion, Community Size, and the Evolution of Fairness and Punishment", 327 Science 1483 (19 March 2010) (emphasis added). "Fairness relates to (but does not identify with) the propriety of distribution between burdens and benefits. Just outcomes are generally those that flow from fair processes. A 'fair trade' (as a 'fair fight') is one conducted under roughly equal conditions." Americo Beviglia-Zampetti, Fairness in the World Economy 27 (2003).

${ }^{26}$ Ernst Fehr \& Simon Gächter, "Fairness and Retaliation: The Economics of Reciprocity" 14:3 Journal of Economic Perspectives 159 (Summer 2000); Joseph Henrich et al., "Markets, Religion, Community Size, and the Evolution of Fairness and Punishment", 327 Science 1480 (19 March 2010) [hereinafter Henrich]. See supporting references in T.C. Burnham et al., 27 Anal. Kritik 113 (2005); M.A. Nowak et al, 289 Science 1773 (2000). See also Karla Hoff, "Fairness in Modern Society" 327 Science 1467-68 (19 Mar. 2010); George Akerlof \& Robert Schiller, Animal Spirits pp. 19-26 (2010).

27 "Evolution: Patience, Fairness and the Human Condition" 950 The Economist 67 (6 Oct. 2007).

${ }^{28}$ See Henrich, supra note 26. 
*. If these findings are accepted, then it becomes apparent that fairness is important both at an individual and a communal level because it is part of a successful evolutionary strategy. In essence, fairness has allowed complex human communities to arise. Many transactions we engage in as humans require us to forego the satisfaction of immediate reciprocation. The guarantee of fairness in these situations - not exact reciprocation, but reciprocation of an approximate type, usually over time - encourages the maintenance and intensification of relationships by affording individuals the security of knowing that at least some their interests will be taken into account. This security encourages participation in communal arrangements.

*. This conclusion, in turn, yields two further observations. The first is that a degree of fairness implies a community. ${ }^{29}$ Thomas Franck defined a community as follows:

A community is based, first, on a common, conscious system of reciprocity between its constituents and this system of reciprocity conduces to a fairness dialogue. This is because a perception of the fairness of any particular rule depends, in major part, on its implicit promise to treat like with like. In order to achieve the expectations that the rule in any one instance will also be the rule in other comparable instances, there must be an underlying assumption of an ongoing, structured relationship between a set of actors: in other words, a community. ${ }^{30}$

*. Franck's description of a community arising from a "fairness dialogue" is a useful reference in the sense that it highlights how fairness concerns arise within relationships and become part of communal concern. However, his description may place undue emphasis on the idea of an "implicit promise to treat like with like" since any set of relationships, or community, will inevitably involve reciprocation over time. This reciprocation will only be approximate, and indeed, in the closest, most enduring relationships, it is likely to be unequal. For this reason, the idea of "like with like" only imperfectly captures what transpires under the rubric of "community".

*. Therefore, a second observation related to the first has to with the convergence between the view of fairness put forward above and recent developments in economics. These suggest that individuals are not purely rational maximizers. In other words, they do not seek to satisfy their own immediate interests, at least not all the time, as economists have long assumed. ${ }^{31}$ Rather, the behaviour of individuals will be calculated to uphold the relationships that are vital to their long-term well-being, something which may require significant discounting or revaluation as the circumstances require and which naturally gives rise to considerations of fairness. There is, therefore, an important element of diffuse and unequal reciprocity in human behaviour.

*. But if fairness is so important and if it has played such a critical role in our evolution as a species, why are communities - including the international community - not entirely fairness-based. Why is the central question we are so often confronted with in international law not the one that Franck posed - "is international law fair?" 32 - but a different one, "is international law just?" A number of commentators have observed that fairness cannot serve as a basis for all law, otherwise the law risks becoming purely political. ${ }^{33}$ Another reason is that the doing of fairness is variable and therefore tends

${ }^{29}$ On the relevance of community see Michael Sandel, Law and the Limits of Liberalism 172-75 (1998). For a look at what makes a community see Peter Block, Community: the structure of belonging (2009).

${ }^{30}$ Thomas Franck, Fairness in International Law and Institutions 10 (1995).

${ }^{31}$ For re-evaluations of econometric analysis of law see Richard Posner, The Failure of Capitalism (2009); Richard Posner, The Crisis of Capitalist Democracy (2010). Nicola De Luca, 'Unequal Treatment and Shareholders' Welfare Growth: 'Fairness' v. 'Precise Equality' 34:3 Delaware J. Corp. L. (2009) (arguing that a strong or rather mechanical equal treatment rule in share repurchases, distributions in kind, or capital reductions is not efficient; an economic analysis of the law shows that disparate treatment of shareholders may increase shareholders' overall welfare).

${ }^{32}$ Thomas Franck, Fairness in International Law and Institutions 7 (1995).

33 "The distinctive features of justice and their special connection with law begin to emerge if it is observed that most of the criticisms made in terms of just and unjust could almost equally well be conveyed by the words 'fair' and 'unfair'. Fairness is plainly not 
to erode stability and predictability. In addition, no community will have the luxury of meeting all claims to fairness. This is because individuals are endlessly different and while sharing the common fact of their humanness, they constantly confront different circumstances. For this reason, not all interests in the form of human needs, wants or desires can be satisfied. As we will see, the 'doing' of fairness imposes a social 'cost' in terms of different logic, rules and requirements. It is not free. Decision-makers must therefore weigh the expense of "doing" fairness in a particular situation against its wider value in reinforcing the sense of communal affiliation. ${ }^{34}$

*. The limitations of fairness suggest that in a complex community - a community where the majority of transactions are impersonal, that is, conducted with strangers with whom we have no regular relationship - another value becomes important. This is the value of equality. Still, equality presents challenges of its own largely because it is impossible for the operation of justice to be completely identical, and in fact, most people in most situations will be content to accept somewhat less or more than they have received in recognition of an ongoing relationship requiring reciprocation in future. Hence, the doing of 'equality' in specific instances is not the same as identity (i.e. equality $\neq$ identity) but more akin to fairness. This reproduction of opposites is, in fact, an aspect of their "nested opposition".

*. The conclusions above can be distilled into a set of relationships that may be expressed as follows:

$$
\text { Justice }=\text { Equality }+ \text { Fairness }
$$

This equation has the advantage of replicating the definition of justice given by a number of legal theorists. ${ }^{35}$ The biological and evolutionary theory set out above, however, also infers that this basic relationship is accompanied by an important proviso:

\section{Equality > Fairness}

*. The proviso stems from the fact that in any complex community the value of equality must exert a

coextensive with morality in general; references to it are mainly relevant in two situations in social life. One is when we are concerned not with a single individual's conduct but with the way in which classes of individuals are treated, when some burden or benefit falls to be distributed among them. Hence what is typically fair or unfair is a 'share'. The second situation is when some injury has been done and compensation or redress is claimed." H.L.A. Hart, The Concept of Law (2 $2^{\text {nd }}$ ed.) 158 (1997). "Conflicts among ideals are common in politics. Even if we rejected integrity and based our political activity only on fairness, justice, and procedural due process, we would find the first two virtues sometimes pulling in the opposite direction. Some philosophers deny the possibility of any fundamental conflict between justice and fairness because they believe that one of these virtues in the end derives from the other. Some say that justice has no meaning apart from fairness, that in politics, as in roulette, whatever happens through fair procedures is just. That is the extreme of the idea called justice as fairness. Others think that the only test of fairness in politics is the test of result, that no procedure is fair unless it is likely to produce political decisions that meet some independent test of justice. That is the opposite extreme, of fairness as justice. Most political philosophers - and I think most people - take the intermediate view that fairness and justice are to some degree independent of one another, so that fair institutions sometimes produce unjust decisions and unfair institutions just ones." Ronald Dworkin, Law's Empire 177 (1986).

${ }^{34}$ Herbert Hart referred to this idea of a limit to the "cost" of enforcement in the following terms: "In civil cases, a similar conflict between justice and the general good is resolved in favour of the latter, when the law provides no remedy for some moral wrong because to enforce compensation in such cases might involve great difficulties of proof or overburden the courts, or unduly hamper enterprise. There is a limit to the amount of law enforcement which any society can afford, even when a moral wrong has been done." H.L.A. Hart, The Concept of Law ( $2^{\text {nd }}$ ed.), p. 166 (1997). There are, of course, some troubling conclusions to the theory of justice and fairness put forward here. A community's resources will be devoted to satisfying certain claims at the expense of others, something which inevitably gives rise to the conclusion that any community will be, in some way, residually unjust. In this respect, two further observations can be made. First, as mentioned, fairness is just, but not all justice is fair. The explanation for this paradox lies in the fact that in a sustainable community justice will be composed of equality and fairness, but there will be some instances where what is just is not fair. This 'residual' unfairness may be a stimulus to communal reform, re-organization or, in certain circumstances, to a radical reformation of the community in the form of revolution, secession or dismemberment. A second conclusion is that communal arrangements reflective of justice will be oriented in a certain way: towards equality and away from fairness. This means that equality will have a certain idealistic and attractive character, something that involves its identification with the future and what will be.

${ }^{35}$ Sanne Taekema observes that "[t]he combination of fairness and equality at the core of the concept of justice is also propagated by Neil MacCormick (1978, 73). Fairness as the core of justice is proposed e.g., by David Miller (1976). Justice as equal treatment can also be found in - apart from Radbruch (1932, 278) Hart (1994, 159), Harris (1996, 171), and Aristotle (1934 Nicomachean Ethics)." Sanne Taekema, The Concept of Ideals in Legal Theory, 192, n. 31 (2003). 
degree of conceptual priority, or 'pull', reflecting the fact that the foundation of any community lies in the application of equal rules to all. Only exceptionally are variable rules, that is, rules tailored to specific circumstances in the form of 'fairness', called for.

*. A critical eye might object to what I have just put forward by pointing out that whole empires have flourished without much idea of equality, at least in a political sense. Sophisticated political structures have been built and sustained for long periods by many impersonal transactions, and hence, the theory that I am asserting is questionable. I recognize this objection, but I also maintain that the theory must be understood in light of contemporary conceptions of equality and fairness which give an ever greater force to the egalitarian impulse (i.e. equality > fairness). Much of the last three hundred years in human history has been devoted to the sweeping away of political structures that, in their earliest phases, must have been based on fairness and replacing them with structures based on ideas of equality. They are a manifestation of the ever more abstract and complex communities we live in, including the international economic community.

*. To summarize, I take a particular view of the concept and role of fairness. Many commentators have had difficulty in defining and identifying what fairness involves and what role it plays, a difficulty I would attribute to the inherent variability of fairness as well as to accreted layers of terminologic and conceptual confusion. Fairness is a subjective value and that subjectivity frequently obscures its definition. I see fairness as playing a certain role in human relations and as part of the idea of justice. It is a necessary attribute of successful relationships and involves a degree of discounting or revaluation in recognition of their maintenance. It might be termed "the justice of particular circumstances". Because fairness is relational, it usually implies a departure from equality. It is inequality for the purpose of sustaining relationships, and therefore in a wider sense, community. However, fairness cannot constitute the basis for all legal rules due to its cost and the need for predictability. The law must be legal, not purely political. Thus, while a general statement of justice might be that justice involves a combination of equality and fairness, in any reasonably complex legal system the law will prioritize equality such that fairness becomes a secondary and supplementary value in the greater task of attaining of equality. Likewise, a legal system giving expression to justice is likely to display its own combination of equality and fairness. ${ }^{36}$

\section{Fairness in International Economic Law}

*. In this section I take a look at how the foregoing theory of fairness is reflected in the shape of legal rules concerning international economic relations. I pursue this examination by analyzing how fairness references and claims are dealt with in terms of equality, rights and proportionality in three areas of international economic law - investment, trade and monetary affairs.

*. I begin the examination in each section of this Part by considering how fairness references are set up against equality in each area. This examination involves consideration of what it is that the law in the area deems to be equal and how fairness, or appropriateness, is shaped in response to this legal priority. Next, I examine how fairness is largely rights-based and is often preoccupied with the particular. For this reason, there are fine limits to what is recognized as fair or appropriate, an aspect of fairness' 'cost'. Finally, as a reflection of this orientation, I examine the law's concern with proportionality in meeting fairness claims. Fairness is measured proportionately, that is, in proportion to its contribution to reinforcing the legal system, and hence, to the community as a whole. Proportionality can also be thought of as a form of 'equality', that is, as an amount equal to the wider notional importance of the proportion. This reality is but a further manifestation of the fact that

\footnotetext{
${ }^{36}$ My ideas about equality and fairness, and therefore justice, bear resemblance to those of Michael Walzer. However, Walzer argues that the criteria of justice should be discerned from analysis of how social goods are actually distributed as opposed to their distribution by some process of abstract reasoning. See Michael Walzer, Spheres of Justice (1983). I go beyond Walzer to suggest that more recent research and abstract reasoning can help to identify a standard typology of justice that involves a combination of equality and fairness.
} 
equality and fairness together form a "nested opposition".

*. The concept of nested opposition was identified by Jack Balkin in 1990 to define "oppositions which also involve a relation of dependence, similarity, or containment between the opposed concepts." ${ }^{37}$ Balkin defined the concept further as follows:

A nested opposition is a conceptual opposition each of whose terms contains the other, or each of whose terms shares something with the other. The metaphor of "containing" one's opposite actually stands as a proxy for a number of related concepts - similarity to the opposite, overlap with the opposite, being a special case of the opposite, conceptual or historical dependence upon the opposite, and reproduction of the opposite or transformation into the opposite over time. ${ }^{38}$

*. What nested opposition stresses are deconstructionist ideas of 'differance' and 'trace'. 'Differance' was the term of art used by Jacques Derrida to describe the mutual dependence and differentiation of concepts. 'Trace' is the retention of absent concepts that remain present in the understanding of other concepts. Differance and trace are relevant in deconstructionist analysis, which aims to show "to show that the favored or dominant term bears some form of conceptual dependence to the disfavored or subordinated term." 39

*. Applying these ideas to international economic relations, we will observe a conceptual dependence between equality and fairness in all three of the areas of international economic law. This conceptual dependence emphasizes the primacy of equality and the subordination of fairness. Equality is the dominant concept, which is generalized and plenary. It is the 'default' to which law generally adheres. Fairness, by comparison, is the "disfavoured" or "subordinated" concept. It is the exception, something which legal rules reproduce irregularly.

*. In line with their character as a nested opposition, however, equality and fairness rules relate to each other symbiotically. If the law is not doing equality, it must be doing fairness, and vice versa. What is perhaps most intriguing is the possibility of "reproduction", or "transformation", between the nested opposites. As will be seen, the actual 'doing' of equality becomes fairness in each momentary instance. Likewise, the 'doing' of fairness becomes our best estimate of what equality looks like over time. Together, the two values exhibit a relationship - a relationship that varies according to the community within which it takes shape and which is commonly conceived of under the rubric of 'justice'.

\section{a. International Investment Law}

*. International investment law is that branch of international law which deals with the regulation of state behaviour vis-à-vis foreign investors and their investments in foreign countries. The law in the area has emerged out of a two-fold concern, one for the taking of property, the other for the protection of aliens. Today it is sourced in both customary international law and in a dense network of almost 3,000 bilateral, regional and multilateral treaties. ${ }^{40}$ Many of these treaties are similar, featuring similar language, provisions and causes of action, but a number also reveal variations that reflect subtle differences in relations between signatory states. The resulting legal framework of international investment protection is therefore highly uneven.

\footnotetext{
${ }^{37}$ Jack Balkin, "Nested Oppositions" 99 Yale L.J. 1669 at 1671 (1990).

${ }^{38}$ Ibid., at 1676.

${ }^{39} \mathrm{Ibid}$.

40 "As a result of the surge in treaty-making undertaken by states since the end of World War II, the total number of treaties with meaningful provisions relating to foreign investment as of the beginning of 2009 probably exceeded 3,000." Jeswald Salacuse, The Law of Investment Treaties 2 (2010).
} 
*. The focus of this framework is overwhelmingly on investor protection. The 'equality' in question is the value of the investment or some proxy thereof. In essence, the law emphasizes the protection and vindication of the investor's rights to equal recovery, although as we will see, this 'equality' is highly variable and, consistent with the theory laid out above, can be thought of in each momentary assessment as 'fairness'. The theory suggests that because of this orientation, international investment law should be replete with instances of fairness - as indeed we will see it is.

*. Under most bilateral investment treaties (BITs) foreign investors have three classic bases of claim:

i) expropriation

ii) a breach of international law

iii) a breach of private law.

These bases of claim are accompanied by standards of treatment. Historically, the taking of property came to be regulated by international law relating to expropriation, legal and illegal takings, whereas rules relating to the treatment of aliens, which initially emphasized the physical treatment of the alien as a person, subsequently evolved to focus somewhat more broadly on the alien as an economic actor.

*. It is within this second category of legal regulation - the treatment of aliens - that a need originally arose to define an international minimum standard of treatment (MST), and ultimately, consideration of what was "fair". The MST was conceived of as a way of sidestepping the pitfalls of a purely national standard. The initial articulation of the standard is commonly traced to the Neer case of 1926, where one commissioner opined that the acts complained of " ... should amount to an outrage, to bad faith, to wilful neglect of duty, or to an insufficiency of governmental action so far short of international standards that every reasonable and impartial man would readily recognize its insufficiency. ${ }^{\prime 41}$ The Neer and other early formulations of the MST were considered to be restrictive and over time gave rise to less onerous ones. Nevertheless, what the various formulations of an MST emphasize is the independent development of the standard by arbitral tribunals. Their methods of interpretation have, moreover, meant a flexible MST standard, one which remains unclear at the margins. As Muthucumaraswamy Sornarajah observes, "The content of the international minimum standard, when it comes to investment protection, will always be problematic ... One knows that there is such a standard but what that standard contains and what its modern limits are, are unclear." 42

*. The formulation of such a variable standard in the form of a concrete cause of action for investors seeking remedies for injury has proven to be particularly problematic because of the perceived need to reference pre-existing customary sources of protection. For a violation of the MST to be made out "a specific rule or pre-existing customary international law must be shown to have been violated." 43 In some cases, as Sornarajah points out, no such rule or law could be identified. For this reason treaty references to a "fair and equitable standard of treatment" (FET) have become important in recent decades and now constitute the basis for an additional cause of action separate and apart from that of the MST, although there remains substantial debate over whether FET simply duplicates, overlaps, or provides something additional to, the MST. ${ }^{44}$

*. References to "fair and equitable treatment" first appeared in U.S. treaties of friendship, commerce and navigation (FCN treaties) in the 1950s and were later repeated in German and Swiss investment

\footnotetext{
${ }^{41}$ United Nations, Reports of International Arbitral Awards, 1926, IV, pp. 60ff.

${ }^{42}$ Muthucumaraswamy Sornarajah, The International Law on Foreign Investment (2 ${ }^{\text {nd }}$ ed.) 329 (2004).

43 Ibid., p. 332.

44 "Many scholars and non-NAFTA tribunals have concluded that the fair and equitable standard, when expressed without qualification or condition, is an autonomous, additional standard whose scope is not limited by the minimum standards required by international law. According to this view, the fair and equitable clause imposes a higher standard of treatment on host states than customary international law does." Jeswald Salacuse, The Law of Investment Treaties 226 (2010).
} 
treaties in the late $1960 \mathrm{~s} .{ }^{45}$ Subsequently, they became much more frequent, with one commentator estimating in 2007 that references to an FET standard appear in approximately 360 treaties. ${ }^{46}$ However, it is only in the last 15 years that FET-related claims have been regularly made. ${ }^{47}$

*. FET is frequently described as an "absolute" standard or obligation, that is, something distinct from MST or other investment-treaty causes of action premised on relative comparisons with minimal or average behaviour. ${ }^{48}$ Over time FET has also evolved into a residual obligation, "available to redress breaches that the more specifically defined obligations of national treatment, most favoured national treatment, performance requirements or expropriation might not remedy, but where the interest in question is still worthy of investor protection." 49

*. Nevertheless, as a substantive matter the standard itself is famously opaque, recalling the inherent subjectivity of "fairness". Thus, Jeswald Salacuse states that "the term 'fair and equitable' is, one may say without exaggeration, maddeningly vague, frustratingly general, and treacherously elastic" 50 , Roland Kläger describes it as "quite controversial in times of rapidly growing arbitral case law"51 and Meg Kinnear notes that "the FET standard continues to defy precise definition." ${ }^{\text {" S2 }}$ Still, FET claims are enormously important today. Kinnear observes, for instance, that "FET is the most frequently pleaded obligation in international investment arbitration." 53

*. The reason for its importance lies in the nature of international investment law. To begin with, international investment treaties have been described as "hybrid". In most instances countries conclude investment treaties between themselves on a bilateral basis with the ultimate aim of protecting their nationals who invest abroad. Thus, the benefit of these arrangements appears to flow to individual investors, who have been likened to "third party beneficiaries" under contract law. ${ }^{54}$ This predisposes the law towards individuality and subjectivity.

*. At the same time, the bare characterization of investors as beneficiaries is misrepresentative. If fairness involves the maintenance of relationships and the sustaining of community, it appears counterintuitive to allow claims for "fair and equitable treatment" in the context of litigation where the relationship in question - normally an investment - has irretrievably broken down and is unlikely to be re-established. How can the examples referred to here be indicative of fairness' ability to protect and promote relationships? A certain paradox appears until it is recognized that the perspective of investment litigation is generally retrospective and therefore raises the question, what should have been done to re-create the relationship at some particular time in the past? There is, in addition, the question of secondary effects. Most modern investment treaties are concluded with a view to facilitating the flow of investment prospectively or going forward. An obligation of fairness confirmed by an arbitrator in one instance will have a positive effect on the general investment climate in others.

45 An OECD Study Paper on FET published in 2004 observed that ““'US FCN treaties with Ireland (1950), Greece (1954), Israel (1954), France (1960), Pakistan (1961), Belgium (1963) and Luxembourg (1963), contained the express assurance that foreign persons, properties, enterprises and other interests would receive "equitable treatment" while others including those with the Federal Republic of Germany, Ethiopia and the Netherlands used the terms "fair and equitable treatment" for a similar set of items involved in the foreign investment process."

${ }^{46}$ Ioana Tudor, The Fair and Equitable Treatment Standard in the International Law of Foreign Investment ix (2008) [hereinafter Tudor].

${ }^{47}$ Ibid., p. 15.

${ }^{48}$ On FET having a non-contingent character Tudor notes "While other clauses were contingent upon an initial treatment or situation established by the host State, the FET standard was absolute, dependent exclusively on international law, and therefore imposing on host States an obligation they could not model according to their own capacities." Ibid., p. 2.

${ }^{49}$ Meg Kinnear, "The Continuing Development of the Fair and Equitable Treatment Standard", Andrea Bjorklund et al. (eds.), Investment Treaty Law - Current Issues 237 (2009) [hereinafter Kinnear].

${ }^{50}$ Jeswald Salacuse, The Law of Investment Treaties 221 (2010).

${ }^{51}$ Roland Kläger, "Fair and Equitable Treatment' and Sustainable Development" in Marie-Claire Cordonier Segger et al. (eds.), Sustainable Development in World Investment Law 241, 243 (2011).

${ }_{52}^{53}$ See Kinnear, supra note 49 at 209.

${ }^{53}$ Ibid.

${ }^{54}$ Alexandra Diehl, The Core Standard of International Investment Protection: Fair and Equitable Treatment, p. 310 (2012) [hereinafter Diehl]. 
There is also the relationship between signatory states to consider.

*. Nevertheless, the character of relationships in investment law is one-sided in the sense that investment treaties are meant to protect individual investors and investments as opposed to the states that they operate in. There is, therefore, diminished concern with the behaviour of the investor in FET claims. ${ }^{55}$ The law's concern with fairness is not reciprocal.

*. A specific investment relationship provides a natural environment for the individualization of the law mentioned above. It is hardly surprising that within this particularized set of circumstances claims to "fair and equitable treatment" have flourished. Case after case in which FET claims have been considered stress the highly subjective nature of fairness analyzed under the standard. Tribunals have repeatedly stressed that a judgment of what is fair and equitable cannot be reached in the abstract. It will always depend on the specific circumstances. Thus, for instance, "[i]n Waste Management, the tribunal interpreting the standard held that 'the standard is to some extent a flexible one which must be adapted to the circumstances of each case." 56

*. In examining the law in this area, it becomes clear that definitions of fairness used by tribunals and commentators accord with the idea of "appropriateness" contained in the theory above. In most instances there appears to be a shade of distinction maintained between "fairness" and cognate concepts of "justice" or "equality". Thus, in MTD Equity v. Chile ${ }^{57}$ the tribunal observed:

... in their ordinary meaning, the terms 'fair' and 'equitable' ... mean 'just', 'evenhanded', 'unbiased', 'legitimate'.

There are, however, limitations to a purely textual approach and commentators in search of a definition of FET have tended to focus on what particular standard it provides substantively - whether equal to, overlapping, or different from the MST - rather than its bare meaning per se. ${ }^{58}$ Meg Kinnear has also observed that "[d]ictionary definitions of the terms 'fair' or 'equitable' tend to be circular, and the meaning of 'fair and equitable' may well be in the eye of the beholder." 59

*. In addition, there are fine limits to investment law's subjectivity and hence to its fairness. This is particularly apparent in relation to the interpretation by arbitrators of investors' "reasonable expectations". Kinnear notes, for instance, that "[t]he most significant development in recent FET cases has been the tendency of awards to go beyond a mere invocation of the mantra that legitimate

\footnotetext{
55 "The legal obligation of the host State to treat foreign Investors fairly and equitably is a unilateral obligation and does not place the Investor in a reciprocal relationship in which he would assume a corresponding obligation.” Tudor, supra note 46 at p. 236.

${ }^{56}$ Tudor, supra note 46 at p. 130. See also CME Czech Republic B.V. v. Czech Republic, UNCITRAL (The Netherlands/Czech Republic BIT) Partial Award 13 September 2001, para 336; Mondev v. United States, para 118; Petrobart v. Kyrgyz Republic, Stockholm Chamber Case No. 126/2003 (Energy Charter) Final Award, 29 March 2005, para 26; Noble Ventures v. Romania (ICSID Case No. ARB/01/11) Award 12 October 2005, para 181; MTD Equity Sdn. Bhd. \& MTD Chile S.A. v. Chile (Republic of) (ICSID Case No. ARB/01/7) (Malaysia/Chile BIT), Award 25 May 2004, para 109; ADC Affiliate Limited and ADC \& ADMC Management Limited v. Hungary (The Republic of) (ICSID Case No. ARB/03/16) (Hungary/Cyprus BIT) Award 2 October 2006, para 44; Waste Management v. Mexico, para 99 cited in GAMI Investments v. Mexico, para 96. Commentators agree. Pierre-Marie Dupuy has referred to FET as "a benchmark for identifying a rule and the rule itself as it is established by taking into account every pertinent element of fact and law to be selected out of the complex relationship existing at a certain time between the investor and the host State." Quoted in Tudor, supra note 46 at p. vi. Tudor notes that "[i]t is the subjective element of the standard that illustrates best its ability to cover and extensive list of hypotheses through its 'open-ended' nature. The variety of facts and circumstances to which the standard is applied speak for themselves." Similarly, Alexandra Diehl observes that, "[i]nvestment standards like the FET standard can thus be described as factually based yardsticks that measure the conformity of a State's action with international law. Being a 'factually based yardstick', the FET standard naturally has to be described in terms of fact patterns." Diehl, supra note 54, at p. 329.

${ }_{57}^{5}$ ICSID Case No. ARB/01/07 Award (25 May 2004).

${ }^{58}$ It is useful to remember, however, that references to a FET standard in international investment law refer to "fair and equitable", meaning that in virtually every instance the definition of fairness and equity coexist and must be interpreted jointly. What they have become, in essence, is a term of art. Credence was given to this idea by Judge Higgins in the Oil Platforms (Iran v. United States) case, where she observed "“The key terms 'fair and equitable treatment to nationals and companies' and 'unreasonable and discriminatory measures' are legal terms of art well known in the field of overseas investment protection ..." [1996] I.C.J. 803 (Preliminary Objection) (emphasis added).

${ }^{59}$ See Kinnear, supra note 49 at 215.
} 
expectations must be met by undertaking a more detailed analysis of the nature of a legitimate expectation." ${ }^{60}$ This has involved tying expectations to pre-investment conditions, the specificity of, and reliance upon, offers, the ultimate objectivity of expectations, and the expectation that the host state will maintain a stable business environment. ${ }^{61}$ Tribunals have demonstrated an awareness that "fair and equitable" claims - as claims that are inherently subjective - must have an objective basis in order to be properly adjudicated upon. ${ }^{62}$

*. Another limitation upon FET claims is the idea of proportionality. Proportionality is the legal principle that all exercises of power must take place in relation to the aim sought to be achieved. In the investment law context, the requirement has been interpreted by some tribunals to mandate a balancing of the investor's rights against the ultimate purpose of official action. Hence in Salukav. Czech Republic ${ }^{63}$ the tribunal determined that a government has the right to regulate its banking sector to promote stability. An investor could not reasonably expect the regulatory environment to remain entirely fixed and static as at the time that its investment was made:

In particular, any differential treatment of a foreign investor must not be based on unreasonable distinctions and demands, and must be justified by showing that it bears a reasonable relationship to rational policies not motivated by a preference for other investments over the foreign-owned investment. ${ }^{64}$

*. Another domain where considerations of fairness rise to the fore in international investment law is in relation to valuation, that is, the valuation of a particular investment by arbitral tribunals. In valuation, the investor's rights are given actual expression. This is where the best estimate of the value of the breached right is arrived at. To recall, international investment law classically recognizes three bases of claim: expropriation, breach of international law and breach of private law. We will see how with respect to each of these bases the ideal of equality - conceived of as "full reparation" - gives way in practice to the reality of fairness.

*. First, with respect to expropriation, it is generally recognized that a state has a presumptive right to expropriate. The state's act in this instance is not regarded as illegal. However upon expropriation, compensation is due. It might be thought that applicable standard of compensation in this instance is one of full repair. Thus, in the Lusitania case the German-American Claims Comission observed that:

It is a general rule of both the civil and the common law that every invasion of a private right imports an injury and that for every such injury the law gives a remedy. Speaking generally, that remedy must be commensurate with the injury received. ${ }^{65}$

Nevertheless, general statements of the law and state practice have not adhered to this view. Instead, the most generally accepted formula with respect to compensation upon expropriation is the Hull Formula of 1938 which describes the relevant obligation being "to make adequate, effective and prompt compensation". This is not identical to the principle of full reparation.

*. Further support for this view of 'equality-as-fairness' comes from the practice of the U.S. and other capital exporting countries. For instance, Art. 6 of the 2012 Model U.S. bilateral investment treaty on 'Expropriation and Compensation' reads:

\footnotetext{
${ }^{60}$ Ibid., p. 226.

${ }^{61}$ Ibid., pp. 226-236.

62 "FET cases have also begun to explore the reasonableness of the investor's expectations. Given that FET is an objective standard, a tribunal should consider whether in all the circumstances the State acted reasonably. The subjective views of the investor do not govern whether the treatment meets the FET standard.” Ibid., pp. 230.

${ }^{63}$ Saluka Investments B.V. v. Czech Republic, Partial Award (2006).

${ }^{64}$ Ibid., para. 307.

${ }^{65}$ Cited in Irmgard Marboe, Calculation of Compensation and Damages in International Investment Law p. 16, para. 2.32 (2009).
} 
The compensation referred to ... shall: (a) be paid without delay; (b) be equivalent to the fair market value of the expropriated investment immediately before the expropriation took place ("the date of expropriation"); (c) not reflect any change in value occurring because the intended expropriation had become known earlier; and (d) be fully realizable and freely transferable.

The language of other modern model BITs concluded by industrialized countries are similarly worded ${ }^{66}$ In general, they refer to the idea of compensation in the case of expropriation without using the adjective "full" or otherwise referring to the principle of reparation. ${ }^{67}$

*. If equality therefore takes the form of "fairness" in the expropriation context, this appears to give credence to the view derived from the theory above that equality in any momentary instance is merely 'fair'. This is true even if equality is 'greater' than fairness at a purely conceptual level (equality > fairness) since it is something that is constantly worked towards.

*. But what then is the relevant standard of compensation in the case of an expropriation? It is useful to note that the language employed in treaties and by tribunals in instances of valuation becomes highly specific and contextualized, with use of such terms as "fair market value", "genuine value", "actual value" and so forth. Moreover, as Irmgard Marboe points out, the idea of value is not objective since "[i]t always depends on a specific relationship between the particular object and a subject." 68 Again, this practice seems to cohere with the relational view of fairness as 'appropriateness'. What is "fair" will depend upon the nature of the relationship, and that, in turn, may involve significant discounting or revaluation in light of the particulars of the relationship.

*. Do these same ideas also hold with respect to the valuation of breaches of international law and breaches of contract? Superficially they would appear not to. In the leading international case on point, The Chorzów Factory, the Permanent Court of International Justice observed:

The essential principle contained in the actual notion of an illegal act - a principle which seems to be established by international practice and in particular by decisions of arbitral tribunals - is that reparation must, as far as possible, wipe out all the consequences of the illegal act and re-establish the situation which would, in all probability, have existed if that act had not been committed. ${ }^{69}$

Chorzów Factory has been referred to on numerous occasions since it was first formulated in 1928. Additional support for this view would appear to come from the International Law Commission's Draft Articles on State Responsibility (DASR), which were concluded in 2001. DASR Art. 31 states:

The responsible State is under an obligation to make full reparation for the injury caused by the internationally wrongful act.

*. These considerations - which involve the law's normativity and the practical difficulties of making full reparation - suggest the ILC formulation tacitly coheres with the view that remediation there will be a shortfall in "full reparation". This lends further support to the view derived from theory that equality in the abstract is greater than fairness in reality (equality $>$ fairness). Actual examples from

\footnotetext{
${ }^{66}$ Ibid., p. 21, para. 2.50.

${ }^{67}$ Ibid., p. 22, para. 2.52

${ }^{68}$ Ibid., p. 22, para. 2.57. See also Paulo Roberto B. Lustosa, "The Fairness of Fair Value: SFAS 157, Irving Fisher and GECON" Electronic copy available at http://ssrn.com/abstract=1814176 (2011) (Fair value measurement is increasingly spreading in accounting standards. In February 2011 the fair value measure was present in 61 FASB pronouncements. Such diffusion led to the issuance of SFAS 157 - Fair Value Measurements, in which many prior definitions and measurement requirements, presented in other pronouncements, were replaced by a single international accounting standard on this subject. But the expansion of situations in which fair value measurement is required makes it more difficult to ensure that the computed measure of value is actually fair.)

${ }^{69}$ Case concerning the Factory at Chorzów, P.C.I.J. 1928 Ser. A. No. 17, 47 (emphasis added).
} 
international investment law also tend to support this view. ${ }^{70}$

\section{b. International Trade Law}

*. International trade law might appear similar to international investment law today in the sense that it is sourced in thousands of bilateral, regional and multilateral treaties, something which has given commentators in recent years cause to complain about a "spaghetti bowl" of diverse obligations. ${ }^{71}$ Nevertheless, this diversity masks a degree of uniformity brought about by the membership of most major economies in the World Trade Organization (WTO). No similar centralizing set of obliagtions exists in the field of international investment.

*. Centralization means that there is a markedly different 'orientation', or 'pitch', to WTO obligations than those found in most international investment agreements. Likewise, the conception of equality is more uniform. Whereas international investment law is rights-oriented and largely retrospective in nature, WTO law is, on the whole, much more obligation-oriented and more evidently concerned with equality going forward. Fairness concerns therefore arise more episodically in WTO law.

*. The law of the WTO Agreement originates in legal arrangements that originally developed under the General Agreement on Tariffs and Trade of 1947 (GATT 1947). At the time of GATT's conclusion the original vision underlying the treaty was one of equality of treatment, as spelled out in GATT Arts. I (Most Favoured Nation obligation) and III (National Treatment obligation). GATT members agreed to bind their tariffs at individually agreed levels, or "ceilings", under GATT Art. II. They then supplemented this commitment with a further commitment to treat all foreign goods as well as they treated the goods of their most favoured trading partner (the MFN obligation in GATT Art. I) and no less favourably than they treated like or similar domestic goods (the NT obligation in GATT Art. III).

*. The effect of these arrangements, however, was less rigourous than a pure equality standard might suggest. In practice it proved difficult, if not impossible, to accord exactly identical treatment to foreign products, meaning that over time the habitual standard of treatment under GATT came to be described somewhat more loosely as one of "non-discrimination".

*. GATT and WTO dispute settlement subsequently made clear that despite the emphasis on treatment, GATT/WTO law ultimately aims at "equality of competitive conditions". ${ }^{72}$ This aim is to be contrasted with a legal system which seeks to guarantee specific trade results. The ultimate end of WTO law is much less ambitious and more evidently instrumental. It is that foreign and domestic goods should encounter the same competitive environment $a b$ initio in the marketplace. ${ }^{73}$

\footnotetext{
${ }^{70}$ This 'downward bias' is hypothesized from the difficulty of assessment noted in many cases and the fact that most statements of the relevant rules are phased restrictively, as for instance U.N. CISG Art. 74 ("Such damages may not exceed the loss which the party in breach foresaw or out to have foreseen) and Article 9:502 of the Principles of European Contract Law (defining the 'General Measure of Damages' as "such sum as will put the aggrieved party as nearly as possible into the position which it would have been if the contract had been duly performed."). Marboe, supra note 65 at p. 31, para. 2.85-87. A distinction is often observed by commentators and authorities concerning damage to a state, regulated on the plane of international law, and damage to an individual, regulated by private law. In some instances both have been regarded as essentially the same. On DASR Art. 36, for instance, Marboe notes that "This general formulation leaves room for interpretation and flexibility. ... In essence, [DASR] Art. 36 determines that the damage must be 'financially assessable'. This, however, represents only a very rough guideline, in particular because this provision does not only include material but also immaterial damage, which is certainly not financially assessable without difficulties." Marboe, supra note 22 at p. 81, para. 3.116 [emphasis added].

${ }^{71}$ The term 'spaghetti bowl' to describe the diversity of overlapping bilateral, plurilateral and multilateral trade agreements is usually traced to Jagdish Bhagwati, who first used the term in "U.S. Trade Policy: The Infatuation with Free Trade Agreements" in Jagdish Bhagwati \& Anne O. Krueger, The Dangerous Drift to Preferential Trade Agreements (1995).

${ }^{72}$ See, for instance, India-Measures Affecting the Automotive Sector, WT/DS146/R, WT/DS175/R, para. 7.316 (21 December 2001). "It is a well established principle under WTO jurisprudence that Article III of the GATT 1994 is to provide equality of competitive conditions for imported products in relation to domestic products.... These competitive conditions are affected even in the absence of actual trade flows, wherever the conditions afforded to imported products are such as to affect their competitive opportunities on the market."

${ }^{73}$ The connection between fairness and the potentiality to compete has been described as follows: "Trade law generally, and Article III
} 
*. The transition from GATT to the WTO Agreement in 1994 involved the expansion of coverage of the basic trade disciplines to cover trade in trade in services as well as trade-related aspects of intellectual property. Although the new areas of coverage introduced some interpretative challenges, the impulse to equality in the form of equal treatment remained strong. Some equality-related terms such as "like", "substitutable", "competitive" or "non-discriminatory" were carried over into new areas of coverage. ${ }^{74}$ However, there was also a recognition that the non-quantitative and ever-more instrumental aspect of the new disciplines would require novel concepts, hence the development of "market access" language in relation to both goods and services, "equivalence" and "mutual recognition" in the field of technical barriers, and "harmonization" in relation to sanitary disciplines. ${ }^{75}$ Each of these innovations can be regarded as a restatement and reinforcement of the primacy of equality within the scheme of the treaty.

*. In the WTO era dispute settlement has also made clear that equality, conceived of primarily as equal treatment, remains the major unstated premise in WTO law. It pervades the entire agreement, acting as a kind of default to which the law automatically returns in cases of uncertainty.

*. This point was made clear in EC - Tariff Preferences ${ }^{76}$, which was a dispute brought by India against the European Communities (EC) regarding certain benefits extended by the EC to some developing countries but not others. The particular issue in question was whether the Enabling Clause, by which developed countries are "enabled" to grant developing countries "special and differential treatment", overrode the basic MFN obligation of GATT Art. I and allowed the EC to favour one developing country over the other. While the WTO Appellate Body repeated that "the MFN principle embodied in Article I:1 is a "cornerstone of the GATT" and "one of the pillars of the WTO trading system""'77, it also observed that "[i]t is simply unrealistic to assume that ... development will be in lockstep for all developing countries at once ..." ${ }^{78}$ Consequently, it found that the Enabling Clause permits "preference-granting countries to "respond positively" to "needs" that are not necessarily common or shared by all developing countries." "N9 Notwithstanding this interpretation, however, the WTO Appellate Body concluded by restating the commitment to equality in the following terms:

An interpretation of "non-discriminatory" that does not require the granting of "identical tariff preferences" allows not only for GSP schemes providing preferential market access to all beneficiaries, but also the possibility of additional preferences for developing countries with particular needs, provided that such additional preferences are not inconsistent with other provisions of the Enabling Clause, including the requirements that such preferences be "generalized" and "nonreciprocal". 80

in particular, focuses on the promotion of economic opportunities for importers through the elimination of discriminatory governmental measures which impair fair international trade. Thus, trade law addresses the issue of the potentiality to compete." Korea - Taxes on Alcoholic Beverages, WT/DS75, 84/R, para. 10.81 (26 Jan. 2009) (emphasis added).

${ }^{74}$ See for instance GATS Arts. II:1 (MFN), Art. XVII (NT), TRIPS Arts. 3 (NT), 4 (MFN).

75 'Market access' in the case of goods means the conditions, tariffs and non-tariff measures agreed by members for the entry of specific goods into their markets. In the case of services it takes on the character of a specific provision, GATS Art. XVI, due to the fact that countries are allowed to condition their service commitments. It may be made subject to various types of limitations enumerated in Article XVI(2). For example, limitations may be imposed on the number of services suppliers, service operations or employees in the sector; the value of transactions; the legal form of the service supplier; or the participation of foreign capital. The obligation of 'equivalence' is provided in TBT Art. 2.7 and requires WTO members to give "positive consideration to accepting as equivalent technical regulations of other Members". 'Mutual recognition' is referred to in TBT Art. 6.3, which strongly encourages members to enter into negotiations with other WTO members to mutually accept conformity assessment results. Finally, 'harmonization', referred to in SPS Art. 3, is the obligation to establish national sanitary and phytosanitary measures consistent with international norms.

${ }^{76}$ European Communities - Conditions for the Granting of Preferences to Developing Countries, WT/DS246/AB/R (7 Apr. 2004).

${ }^{77}$ Ibid., para. 101.

${ }^{78}$ Ibid., para. 160.

${ }^{79}$ Ibid., para. 162.

${ }^{80}$ Ibid., para. 169 (emphasis added). 
The commitment to equality therefore varies with the particular WTO provision and national measure in question. ${ }^{81}$

*. Despite this, ever since the creation of GATT in 1947 there has been recognition of the need to temper the idealism of equal treatment with selective departures that take account of actual conditions. ${ }^{82}$ This is where fairness considerations normally arise. In fact, the Appellate Body's interpretation in EC-Tariff Preferences bears this point out. There, developing countries successfully made the point that their development needs were not all the same, and that therefore, the EC could differentiate between them. Such tempering can be thought of as "fairness" in the sense that it responds to real conditions. The law is not keyed to trade as it is prospectively expected, but in some sense as realistically unequal, a fact that must be responded to by action that is "appropriate" in the hope of readjusting the underlying trading relationships and maintaining community.

*. Thus, in addition to basic requirements of non-discrimination, GATT included disciplines on antidumping (Art. VI), countervailing duties (Arts. VI and XVI) and safeguards (Art. XIX). In each instance, member countries were given the right to depart from liberalization requirements where existing conditions of trade do not match those that are initially expected.

*. The key to understanding these "flexibilities" is the idea that they involve a right to depart in some way from the broad, generally restrictive, obligations contained in the treaty. The departures introduce fairness considerations into the law. The treaty allows such flexibility in recognition of the "reality" that countries would never participate in a trading system where equality of competitive conditions was eroded by dumped or subsidized goods, or where countries had no options to selective close their border in the face of threatened or actual injury from foreign competition. ${ }^{83}$ In other words, trading relationships would be eroded, or never come about at all, if the trading environment as between competitors was manifestly "unfair". Hence, the fairness of anti-dumping, countervailing or safeguard action permits appropriate counteraction to preserve the integrity of the trading system and hence the community. A number of commentators have recognized this in the way that these rights serve as "outs" in particular circumstances, and how in doing so, they serve to build support for trade liberalization by assuring limited "safe harbours" for affected interests. ${ }^{84}$ In this way, the larger project of "free" trade is able to move forward.

*. Express references to fairness appear at several points within the WTO Agreement consistent with these ideas. These references may be broadly classified as preambular, procedural and substantive.

\footnotetext{
${ }^{81}$ For instance, 'equality-as-identity' is apparent in GATT Art. I:1 (MFN) and Art. V:2. See Colombia - Ports of Entry, WT/DS366, para. 7.402 (Apr. 27, 2009). However, under GATT Art. III:4 equality is expressed as "treatment no less favourable", meaning the treatment may be formally different but still no less favourable, as discussed in Korea - Beef, WT/ DS161, 169/AB/R. para. 137 (Dec. 11, 2000). Hart also postulated the idea of "approximate equality" as part of the "minimum content" of natural law: H.L.A. Hart, The Concept of Law ( $2^{\text {nd }}$ ed.) 195 (1997). This would appear to confirm the further proviso that equality is not identity (i.e. equality $\neq$ identity), at least not all of the time.

${ }^{82}$ In its original proposals for an international trade organization in 1945 the U.S. put forward the view that: "No government is ready to embrace "free trade" in any absolute sense. ... Every country has its own kind of [trade] restriction, adapted to its own situation, and can hardly be expected to throw off its armor unless the other kinds of armor, employed by other countries, are thrown off at the same time. What is needed is a broad and yet detailed agreement, among many nations, dealing at one time with many different sorts of government restrictions upon trade, reducing all of them at once on a balanced and equitable basis, and stating rules and principles with which the restrictions permitted to remain should be administered." From "Statement by President Truman and Prime Minister Attlee" (Dec. 6, 1945), reprinted in XII Department of State Bulletin 905, 915 (Dec. 9, 1945).

${ }^{83}$ The Appellate Body in Argentina - Footwear noted, for instance, that the fairness considerations in safeguard actions are essentially for a defensive purpose: " $\ldots$ it is essential to keep in mind that a safeguard action is a "fair" trade remedy. The application of a safeguard measure does not depend upon "unfair" trade actions, as is the case with anti-dumping or countervailing measures. Thus, the import restrictions that are imposed on products of exporting Members when a safeguard action is taken must be seen, as we have said, as extraordinary. And, when construing the prerequisites for taking such actions, their extraordinary nature must be taken into account." Argentina - Safeguard Measures on Imports of Footwear, WT/DS121/AB/R, para. 94 (14 Dec. 1999).

${ }^{84}$ For description of the way in which built-flexibility has been critical to the survival of GATT and the WTO Agreement see J.H. Jackson, World Trade and the Law of GATT 30 (1969); J.H. Jackson, The Jurisprudence of GATT and the WTO 189 (2000); A.F. Lowenfeld, International Economic Law 41, 42 (2002).
} 
*. To begin with, there are a few preambular references to fairness. For instance, in the preamble of the WTO Import Licencing Agreement (ILA) mention is made of "the fair and equitable application and administration" of import licencing procedures, procedures that take normally place in the context of a particular encounter between an importer and a national customs administration. Here the possibility for abusive, and hence unfair, conduct is evident. The ILA attempts to limit this sort of behaviour by requiring governments to publish sufficient information for traders so that they can know how and why licences are granted. ILA Art. 1(3) also provides that "rules for import licencing procedures shall be neutral in application and administered in a fair and equitable manner."

*. Similarly, the preamble of the WTO Agreement on Agriculture (AA) recalls a long-term objective of international negotiations in the field of agriculture being "to establish a fair and market-oriented agricultural trading system". This particular reference has to be understood in light of perceived inequity in the existing global framework for agriculture in which developed countries continue to subsidize production and suppress developing country export opportunities ${ }^{85}$ Again, it is important to note how the issue of fairness pits developing countries against developed ones and the particularities of this relationship.

*. A second set of fairness considerations in WTO law arises procedurally in administrative proceedings, where foreign imports or importers can be the victim of national bias. This bias is often an issue in anti-dumping proceeding, where a comparison must be made between the exported price and the normal value in the producer's home market for the purposes of calculating a margin of dumping. Thus, for instance, Art. 2.4 of the Anti-Dumping Agreement provides that in calculating margins of dumping "A fair comparison shall be made between the export price and the normal value." The obligation is for national authorities to ensure that assessments of price are made that accurately reflect comparable conditions. In EC - Bed Linen a WTO panel had an opportunity to expand on comparability in light of the obligation of fairness as follows:

... Read in light of the obligation in the Article 2.4 to make a fair comparison, the specific requirements to make comparisons at the same level of trade and at as nearly as possible at the same time, and the obligation to make due allowance for differences affecting price comparability, the use of the word comparable in Article 2.4.2 indicates to us that investigating authorities may insure comparability either by making necessary adjustments under Article 2.4, or by making comparisons for models which are, themselves, comparable. ${ }^{86}$

The panel's reference to a comparison "at the same level of trade and at as nearly as possible at the same time" speaks to the circumstantial nature of a "fair" assessment. In essence, the treaty requires the comparison must be tailored to circumstances that are as close as reasonably possible to original conditions in the country of production which are 'appropriate'. This could be accomplished either by one of the methods set out in ADA Art. 2.4 or some comparable model. Because the EC had not done so fully, it was found to have breached its obligation.

*. Occasionally, the procedural obligation of fairness in WTO law is something projected into national legal systems. Thus in Brazil - Dessicated Coconut, for instance, the Appellate Body observed that:

[b]ecause a countervailing duty is imposed only as a result of a sequence of acts, a line had to be drawn, and drawn sharply, to avoid uncertainty, unpredictability and

\footnotetext{
${ }^{85}$ Martin Khor of the Third World Network has observed, "[the WTO Agreement on Agriculture] is imbalanced in many ways. It has been fashioned in such a way as to enable developed countries to continue high levels of protection, whilst many developing countries have liberalised and their farmers are facing severe and often damaging competition, often from imports artificially cheapened through subsidies." See Martin Khor, "The WTO Agriculture Agreement: Features, Effects, Negotiations and What is at Stake" 1 (n.d.).

${ }^{86}$ European Communities - Anti-Dumping Duties on Imports of Cotton-Type Bed Linen from India, WT/DS141/R, para. 6.117 (Oct. $30,2000)$.
} 
unfairness concerning the rights of states and private parties under the domestic laws in force when the WTO Agreement came into effect. ${ }^{87}$

*. More often, however, issues of fairness are raised in a variety of circumstances arising within WTO proceedings themselves. ${ }^{88}$ Like the duty of fairness in English and continental systems of administrative law, these involve situations where specific rights are in play and where the decision in question has some particular importance to an individual WTO country as opposed to another ${ }^{89}$ Thus WTO dispute settlement, which takes place largely according to a bilateral matrix involving a single complainant and a single respondent, or small clusters of these, has been described as aimed at providing "fair, prompt and effective resolution" of trade disputes. ${ }^{90}$

*. Within these proceedings the WTO Appellate Body has also referred to a requirement of due process. Due process, in turn, has been described as "fundamental to ensuring a fair and orderly conduct of dispute settlement proceedings". ${ }^{91}$ In Canada - Continued Suspension due process was described as guaranteeing "that the proceedings are conducted with fairness and impartiality, and that one party is not unfairly disadvantaged with respect to other parties in a dispute." ${ }^{22}$ Similarly, in Chile - Price Band System the Appellate Body observed that "[a] panel will fail in the duty to respect due process if it makes a finding on a matter that is not before it, because it will thereby fail to accord to a party a fair right of response. ${ }^{93}$ In Canada - Continued Suspension the Appellate Body also observed that the allocation of the burden of proof in compliance proceedings was, among other considerations,

${ }^{87}$ Brazil-Measures Affecting Dessicated Coconut, WT/DS22/AB/R, p. 19 (Feb. 21, 1997).

${ }^{88}$ Marion Panizzon, "Good Faith, Fairness and Due Process in WTO Dispute Settlement Practice" in Julian Chaisse \& Tiziano Balmelli (eds), Essays on the Future of the World Trade Organization (Vol. II - The WTO Judicial System: Contributions and Challenges) (2008).

${ }^{89}$ In surveying this law of rights/law of fairness it is useful to keep in mind that there is an analogous body of jurisprudence in English law and the law of other common law jurisdictions concerning the "duty of fairness" in administrative proceedings: see William Wade \& Christopher Forsyth, Administrative Law (10 ${ }^{\text {th }}$ ed.) 402 (2009); David Jones \& Anne S. de Villars, Principles of Administrative Law ( $5^{\text {th }}$ ed.) 253 (2009). This body can help to inform and supplement the theory put forward above given that what fundamentally is at issue as in many cases of fairness in international economic law is the relationship between government and the individual. In the domestic context courts have held that administrative tribunals and bodies owe a duty to be fair - usually conceived of as a duty to take into account the specific circumstances of the applicant - whenever the applicant's rights are specially affected. The duty can be thought of as an individualization of the procedure to the applicant, or in other words, an obligation of "appropriateness". The Supreme Court of Canada observed in Baker v. Canada that:

[t]he values underlying the duty of procedural fairness relate to the principle that the individual or individuals affected should have the opportunity to present their case fully and fairly, and have decisions affecting their rights, interests, or privileges made using a fair, impartial, and open process, appropriate to the statutory, institutional, and social context of the decision.

[1999] 2 S.C.R. 817, para. 28. For comment see Grant Huscroft, "From Natural Justice to Fairness - Thresholds, Content and the Role of Judicial Review" manuscript available at www.ssrn.com, abstract 2013253 (May 24, 2012).forthcoming in Colleen Flood et al. Administrative Law in Context ( $2^{\text {nd }}$ ed.). Again, the reference to "rights, interests or privileges" and the insistence on particularization is especially notable. The passage from Baker speaks of a desire to tailor procedures and outcomes to the specific rights in question, thereby affirming the relationship between the state and the claimant. It also speaks to the point that law, which is largely instrumental, is best equipped to achieve procedural as opposed to substantive fairness. The same point has been made by other commentators who have referred to similar fairness principles developed in the context of European and EU administrative law. See for instance Stephan W. Schill, "Fair and Equitable Treatment under Investment Treaties as an Embodiment of the Rule of Law", IILJ Working Paper 2006/6. Schill observes that "the rule of law understanding underlying the jurisprudence of investment tribunals can be described as primarily procedural and institutional in nature." Ibid., p. 43. Schill also makes the point that jurisprudence of the European Court of Human Rights or under the European Convention on Human Rights "could ... be used to further concretize fair and equitable treatment, for example, with respect to the timely administration of justice or the right to a fair trial. Similarly, comparative recourse could be had to the emerging principles of European administrative law or the jurisprudence of the WTO Appellate Body in order to further develop the rule of law requirements with respect to the exercise of public power." Ibid., p. 34.

${ }_{90}$ The Appellate Body has noted, "The procedural rules of WTO dispute settlement are designed to promote, not the development of litigation techniques, but simply the fair, prompt and effective resolution of trade disputes". United States - Tax Treatment for "Foreign Sales Corporations" ("US - FSC"), WT/DS108/AB/R, para. 166 (Feb. 24, 2000) (emphasis added).

91 Thailand - Anti-Dumping Duties on Angles, Shapes and Sections of Iron or Non-Alloy Steel and H-Beams from Poland, WT/DS122/AB/R, para. 88 (March 12, 2001).

${ }_{92}$ Canada - Continued Suspension of Obligations in the EC - Hormones Dispute, WT/DS321/AB/R, para. 433 (Oct. 16, 2008).

${ }_{93}$ Chile - Price Band System and Safeguard Measures relating to Certain Agricultural Products, WT/DS207/AB/R, para. 176 (23 Sept. 2002). 
a matter of "procedural fairness". ${ }^{94}$ And again, in Chile - Price Band System an arbitrator assessing the reasonable period of time (RPT) for implementation by Chile noted that the RPT chosen "will fairly balance the legitimate needs of the implementing Member against those of the complaining Member. "95 Once more, the recurrent issue in fairness involves the characteristics of relationships among members and between tribunals and litigating parties.

*. Considerations of substantive fairness are perhaps more pervasive, but less often express and therefore harder to identify, in WTO law. I have already referred to the "flexibilities" of WTO law and the way in which these give member countries the right to derogate from their obligations in certain instances.

*. Another related set of flexibilities that raise fairness considerations in WTO law involve formal exceptions. Every legal system must have exceptions that allow for selective release from generalized rules. In the case of GATT, for instance, these are found most notably in GATT Art. XX, where countries have the right to depart from liberalization requirements in the pursuit of certain defined policy objectives. The applicable method of justification is two-fold. First, a country must prove that it has met the terms of the relevant exception. Second, it must subsequently prove that it has met the terms of GATT Art. XX's preamble, which the Appellate Body has emphasized focuses attention on the application of the measure at issue. The analysis centers on whether there is adequate justification for the measure when compared with other, similar situations.

*. Not surprisingly, the invocation of exceptions has led to rigourous analysis of their extent in WTO jurisprudence. A number of cases and commentators have pointed out that exceptional behaviour in the form of rights must not be allowed to vitiate the rights of other WTO members. Consequently, there have been a number of references in case law to doctrines such as abuse of rights, proportionality and estoppel that suggest a preoccupation in these instances with definition, conditioning and limitation. ${ }^{96}$ The preoccupation stems directly from the exceptions which, while required to respect state sovereignty and to tailor the law to individual circumstances in the manner of "fairness", are not unrestricted. For instance, in interpreting the word "necessary" in GATT Art. XX(b) the panel in Brazil-Tyres observed:

The necessity of a measure should be determined through 'a process of weighing and balancing of factors' which usually includes the assessment of the following three factors: the relative importance of interests or values furthered by the challenged measures, the contribution of the measure to the realization of the ends pursued by it and the restrictive impact of the measure on international commerce. ${ }^{97}$

*. A further consideration of substantive fairness arises in cases of WTO retaliation where member countries are entitled to retaliate against other countries' breaches of the WTO Agreement. On the surface the law appears to mandate an equality standard. Thus, Art. 22.4 of the WTO Dispute Settlement Understanding (DSU) provides that:

The level of the suspension of concessions or other obligations .... shall be equivalent to the level of the nullification or impairment.

\footnotetext{
${ }^{94}$ Canada-Continued Suspension, supra, note 94 at para. 361.

${ }^{95}$ Chile - Price Band System and Safeguard Measures relating to Certain Agricultural Products (21.3), WT/DS207/13, para. 37 (17 Mar. 2003).

${ }^{96}$ For instance, in U.S. - Shrimp the Appellate Body observed in relation to the preamble, or chapeau, of Art. XX that "The task of interpreting and applying the chapeau is, hence, essentially the delicate one of locating and marking out a line of equilibrium between the right of a Member to invoke an exception under Article XX and the rights of the other Members under varying substantive provisions (e.g., Article XI) of the GATT 1994, so that neither of the competing rights will cancel out the other and thereby distort and nullify or impair the balance of rights and obligations constructed by the Members themselves in that Agreement." U.S. - Import Prohibition of Certain Shrimp and Shrimp Products, WT/DS58/AB/R, para. 159 (12 Oct. 1998) (emphasis added).

${ }^{97}$ Brazil - Measures Affecting Imports of Retreaded Tyres, WT/DS332/R, para. 7.104 (12 June 2007).
} 
Thus, for instance, in the Bananas dispute between the U.S. and EU, the U.S. was authorized to retaliate against the EU in the amount of \$201.6 million annually for EC tariff restrictions on foreign bananas. The U.S. implemented the retaliation in the form of additional duties on a range of EU agricultural products in the period 2000-09 until the dispute was finally settled. Such retaliation is temporary and to be invoked "as a last resort". 98

*. Several commentators have pointed out, however, the opacity of the retaliatory equivalence standard. ${ }^{99}$ What exactly is "equivalent to the level of the nullification or impairment" and how is it to be implemented? It might seem reasonable to assume that nullification or impairment should be tied to the detrimental trade effects of a violation, but even this initial issue is unclear given that the MFN obligation infers that a single violation may have multi-directional effects within the trading system. Thomas Sebastian has noted that there are potentially four issues arising in an equivalence determination:

Arbitrators have to (1) specify the baseline from which they wish to assess the detrimental effects of the concerned measures; (2) settle on a metric for measuring these effects; (3) determine which detrimental effects will be considered; and (4) resolve any empirical issues that may arise. ${ }^{100}$

Sebastian and others have detailed the arbitrary nature of all of these inquiries and the fact that, taken together, the aggregate assessment of them is conceptually unconvincing.

*. Perhaps the greatest complaint of the retaliatory standard is the fact of its limited intensity. Many commentators have observed that a strict equivalence standard for retaliation provides no real incentive to comply. Sebastian concludes with palpable frustration that:

The search for an instrumental rationale to guide arbitrators leads us to conclude that many theories cannot be reconciled with the structure of the remedial provisions of the DSU, are not achievable in practice, or are simply incoherent. ... It follows that, unless one endorses the retribution rationale, one must conclude that the bulk of the WTO remedial regime relating to the permissible intensity of retaliation is simply bereft of any valid rationale. ${ }^{101}$

*. Nevertheless, it is useful to consider exactly why an equivalence standard might make sense on the theory put forward in this article and how the conclusions of Sebastian and others can be reformulated so as to be more logically and naturally understood as instances of "fairness".

*. My conclusion would appear to be nonsensical if considered in light of the treaty's plain directive that the amount of retaliation should be "equivalent to the level of the nullification or impairment". But it is intelligible if seen against a broader background of the treaty - a background composed of all the transactions within series of trading relationships taken together. Shortfalls in the assessment of nullification or impairment routinely occur because WTO members expect their relationships to continue and are therefore content to contemplate such a result. Like private actors in any 'community', WTO members will be content to accept permission to retaliate for somewhat less or more than the damage they have sustained in recognition of an ongoing relationship requiring

\footnotetext{
${ }^{98}$ See DSU Art. 3.7 ("The last resort which this Understanding provides to the Member invoking the dispute settlement procedures is the possibility of suspending the application of concessions or other obligations under the covered agreements ...").

${ }_{99}$ See for instance Thomas Sebastian, "World Trade Organization Remedies and the Assessment of Proportionality: Equivalence and Appropriateness" 48:2 Harvard Int'l L.J. 337 (2007) [hereinafter 'Sebastian']; Bryan Mercurio, "Retaliatory Trade Measures in the WTO Dispute Settlement Understanding: Are there Really Alternatives?" in James C. Hartigan (ed.), Frontiers of Economics and Globalization - Vol. 6, 397 (2009) [hereinafter 'Mercurio'].

${ }^{100}$ Sebastian, ibid., p. 351.

${ }^{101}$ Sebastian, ibid., pp. 378-379.
} 
reciprocation in future. The equality language contained in DSU Art. 22.4 is valuable, however, because it gives the system a touchstone to aim for. In this sense, the aspiration to equality is important for the promotion of community even if it is never fully nor satisfactorily realized. ${ }^{102}$

*. These illustrations of the tension between notions of equality as an abstract ideal and the determination of what is fair in specific circumstances should also help to clarify the overarching purpose of WTO remedies and of WTO law. This purpose is manifestly different from that of international investment law, which aims to vindicate investor rights for the larger purpose of promoting investment flows. ${ }^{103}$ If we understand the contrasting roles of equality and fairness as manifestations of justice, it becomes apparent that the WTO's remedial system may have a mix of conventionally accepted purposes: compensation, coercion, compliance. Chief among these purposes, however, is the idea of transformation, something that leads to the modification of legal relationships and comports well with the idea that fairness is, ultimately, about their maintenance and the maintenance of a community. ${ }^{104}$

\title{
c. International Monetary Law
}

*. Like both the international regulatory regimes for investment and trade, the current international regime for monetary affairs originated at the Bretton Woods Conference of 1944. During the course of the conference representatives of member countries signed Articles of Agreement that created the International Monetary Fund.

*. The organization's basic aims are several-fold, but its over-arching objective is to promote the stability in the international monetary system and avoid competitive devaluations that contributed to the economic and political chaos during the interwar period (1919-39) and eventually led to World

\begin{abstract}
${ }^{102}$ Such considerations are perhaps even more apparent in the realm of WTO disciplines on subsidies. The WTO Subsidies Agreement (SCM) Art. 3 allows countries to complain against export subsidies, that is, subsidies which are conditioned on exports or on schemes of import substitution. In the event that a violation is found, SCM Art. 4.10 provides that the WTO "shall grant authorization to the complaining Member to take appropriate countermeasures ...." An accompanying footnote explains that the term "appropriate" "... is not meant to allow countermeasures that are disproportionate in light of the fact that the subsidies dealt with under these provisions are prohibited." The standard of "appropriateness" is evidently different from the equivalence standard found in DSU Art. 22.4. In three instances arbitrators assessing retaliation under DSU Art. 22.6 have considered this difference in determining what is "appropriate". Thus, in Brazil - Aircraft (Article 22.6) the arbitrators observed that the difference did not require an equality-of-harm approach as is normally the case under DSU Art. 22.4 and instead decided that "a countermeasure is appropriate inter alia if it effectively induces compliance." WT/DS46/ARB, para. 3.44 (Aug. 28, 2000). In U.S. - FSC (Article 22.6) the issue was tax credits received by U.S. firms for certain overseas operations, something that was found to amount to an export subsidy. Because there was no easy way of calculating the exact benefit conferred on U.S. companies, the arbitrators determined that "appropriate" involved the "imposition on firms of the Member concerned of expenses at least equivalent to those initially incurred by the treasury of the Member concerned in granting benefits to its firms." U.S. - FSC, WT/DS108/ARB (Aug. 30, 2002). Finally, in Canada - Aircraft (Article 22.6) the arbitrators noted that the complainant, Brazil, had failed to substantiate a causal link between the subsidy and the sales lost by a Brazilian manufacturer so that the typical equality-of-harm approach could not be usefully applied. In the alternative, the arbitrator decided to base "appropriate countermeasures" on the amount of the subsidy conferred, but also added a 20 percent top-up, or premium, to this amount in recognition of the fact that Canada has made clear its refusal to withdraw the subsidy. It is noteworthy that in coming to their specific conclusion, the arbitrators took into account a number of factors that had the effect of further particularizing the relief. See Canada - Aircraft (II), WT/DS222/ARB, para. 3.121 (Feb. 17, 2003). The "individuality of the law" here is apparent.

${ }^{103}$ Again, many commentators have expressed bewilderment at the shape of WTO remedies. Thus, Bryan Mercurio has noted: ... the system, as written and interpreted, does not have clear aims and objectives (beyond simply resolving the dispute). The question of whether the retaliatory phase of the process is designed to rebalance concessions, coerce compliance or punish recalcitrant respondents is simply not clearly addressed in the text of the DSU. See Mercurio, supra note 101, p. 431.

${ }^{104}$ In conventional thinking about WTO remedies this is often referred to as "rebalancing." Sebastian describes rebalancing as follows:
\end{abstract}

In effect, under this approach arbitrators are being asked to rewrite the WTO Agreements between two WTO Member states. But they have no guidance about what the reformulated agreement should look like. To arrive at this reformulated agreement they would need to know, at the outset, the precise content of the underlying bilateral bargain between the concerned countries. However, this knowledge is simply not attainable. For a variety of reasons, an arbitrator has not practical way to determine the "price" paid by State R for State V's commitment to abide by the obligation breached.

Sebastian, supra note 101, p. 371. Sebastian dismisses the rebalancing function as a plausible purpose of WTO remedies because he conceives of the relationship between two WTO members, and more broadly and diffusely between the entire membership, in starkly empiric terms of a "price" rather than as I do, metaphorically for an entire set of economic, political and social priorities. 
War II. For this reason, the Articles originally provided for a system of managed exchange rates, or "pegs", tied to gold. Over time the system proved unsustainable, something which led to its abandonment and reform in the early 1970s.

*. Since 1977 IMF member countries have essentially been free to set their own exchange rates. This freedom can take the form either of a peg, a "managed float", or a free float, as set out in Art. IV:2(b). However the freedom, or right ${ }^{105}$, is accompanied by an important obligation contained in Art. IV:1(iii):

[Each member shall] avoid manipulating exchange rates or the international monetary system in order to prevent effective balance of payments adjustment or to gain an unfair competitive advantage over other members.

According to Rosa Lastra the obligations spelled out in Art. IV are "rather generic in their formulation ('endeavour to ...', 'seek to promote ...') with the exception of Article IV, section 1(iii), which specifically requests members to" 106 avoid currency manipulation for the particular purposes mentioned. ${ }^{107}$

*. Making determinations under Art. IV:1(iii) is problematic. Determining whether a country is preventing effective balance of payments adjustments or "seeking to gain an unfair competitive advantage over other members" is not easily measured under conventional economic analysis. Nevertheless, since the early 2000s the content of the obligation under Art. IV:1(iii) has come to be at the centre of a dispute ongoing between the U.S. and China over China's valuation of its currency, the renminbi (RMB). The dispute has arisen in the shadow of a growing U.S.-China trade relationship which, by some measures, has become the largest bilateral trade relationship in the world. ${ }^{108}$

*. The currency dispute between the U.S. and China has simmered for several years and given rise to threats of retaliatory legislation in the U.S. Congress. ${ }^{109}$ Nevertheless, China's currency continues to fuel Chinese exports, which remain attractively priced for foreign buyers, including Americans, thereby contributing substantially to the U.S. trade deficit. The result is a steady erosion of the competitiveness of non-Chinese producers of many goods. Not surprisingly, many Americans are of the view that China's currency valuation practices are "unfair".

*. The particular claim to unfairness here arises within the context of the U.S.-China trade relationship. To understand the sensitivities it raises, additional background on the functions and workings of the IMF are in order. The commitment to equality in IMF operations is a purely legal one.

\footnotetext{
${ }^{105}$ Relationships are classically conceived of in law in terms of rights and obligations. A right "affirms the desiring and hence the willing of the right-holder." The correlative of a right is an obligation, which is said to "constrain[] the willing of the duty-holder." Philip Allott observes that by legal relation in the form of a right, "society is considered to confer on the right-holder the benefit, the protection, the assurance, the individuality of the law." Likewise, by legal relation in the form of an obligation, "society is considered to impose on the duty-holder the burden, the order, the universality of the law." Philip Allott, Eunomia p. 159-160 (II 10.43) (1990).

${ }^{106}$ As an example, Lastra mentions the case of Sweden's violation of the obligation in 1982, but also notes that the IMF Executive Board "took no specific formal decision nor imposed any sanction" in that case. Rosa Lastra, Legal Foundations of International Monetary Stability 365 (2006).

${ }^{107}$ Ibid., 366.

${ }^{108}$ The Office of the U.S. Trade Representative estimated in 2011 that China was the U.S.'s second largest goods trading partner and the largest supplier of U.S. goods imports. See Office of the U.S. Trade Representative, http://www.ustr.gov/countries-regions/china (consulted Oct. 12, 2012).

${ }^{109}$ For a summary of proposed retaliatory legislation see Wayne M. Morrison \& Marc Labonte, "China's Currency: An Analysis of the Economic Issues" Congressional Research Service Report RS21625 (Jan. 12, 2011). At the same time the U.S. Treasury Department's most recent review of global exchange-rate policies, published in May 2012, concluded that China does not meet the criteria to be labelled a currency manipulator. Indeed, the Treasury report points out that China's exchange rate is a better reflection of fair value than it has been in years - though it maintains the currency distortions remain significant. "China is gradually allowing necessary external adjustments to take place, as indicated by the decline in China's current account surplus together with real appreciation of the [yuan] since June, 2010, and China's steps to gradually open its capital account," the report said. "Nevertheless, the underlying factors that distort China's economy and constrain global demand growth remain." See U.S. Treasury, "Semiannual Report on International Economic and Exchange Rate Policies” p. 4 (May 2012).
} 
It is rooted in the fact that each country has an equal sovereign right to establish its own exchange rate. Formally speaking, there is no notion of "equal compensation" as in international investment law or the "equality of competitive conditions" as in WTO law. The international monetary system, which is composed of hundreds of exchange rates that fluctuate daily, is reflective of so many diverse forces and priorities that it is probably beyond the ability of governments and international financial institutions to entirely control. At the same time, governments constantly intervene to support or depreciate their currencies. ${ }^{110}$

*. The prevailing complexity of the international monetary system means the IMF's primary function is chiefly as a 'surveillance' institution. This surveillance is carried on annually on a bilateral basis with each member country. Surveillance has been described as follows:

The purpose of surveillance is to evaluate the appropriateness of a country's existing policies and at the same time to encourage the country to adopt new policies that enhance the smooth functioning of the international monetary system. IMF surveillance integrates the bilateral aspects of analyzing the policies of individual countries with the multilateral aspects of examining the consequences of these policies for the operation of the system as a whole. ${ }^{111}$

Lastra notes that the conclusions of surveillance reports are only published if a country consents. ${ }^{112}$ Thus, apart from the ability of the organization to deny, or at least heavily condition, fulfillment of members' individual requests for assistance from the Fund, there is little that the IMF can do to force a country to adopt its prescriptions. Certain countries, like Malaysia during the Asian Financial Crisis of 1997-98 or Argentina in early 2001, plainly refused to do so, with mixed results.

*. The Fund's loose normativity means that what has emerged instead is generally recognized to be a regime of 'soft law', that is, a regime whose norms are non-binding as a legal matter and largely aspirational in nature. Lastra notes:

Since Article IV imposes obligations upon members, sanctions can be applied in the case of breach of these obligations. However, 'there has not been a single instance in which sanctions have been applied or a report has been made for breach of an obligation under Article IV. This de facto transformation of Article IV section 1 into a "soft law provision" is reflected in the description of Article IV consultation with members as "policy advice" ... or "policy dialogue"."113

*. The basic problem in the U.S.-China currency dispute is therefore one of insufficient normativity. Individual country's rights within the system have not been reconciled and integrated within a framework of corresponding obligations. There remains considerable flexibility, or 'play', that takes the shape of soft law. Here, fairness claims are tenous and often hard to make out.

*. Still, one growing problem in recent decades has been the size of trade surpluses and deficits, something recognized as long ago as 1977 as potentially contributing to financial and economic instability. Thus, in the IMF Executive Board's 1977 Decision, "Surveillance over Exchange Rate Policies" mention was made of the duty of countries to avoid "manipulating their exchange rates .... to gain an unfair competitive advantage over other members" and "Members should take into account in their intervention policies the interests of other members". In 2007 an Executive Board re-iterated

\footnotetext{
${ }^{110}$ China is far from the only country in the world without a free-floating currency, nor is it alone in pulling policy levers that influence exchange rates. (Critics have recently suggested the manipulator label could just as easily be applied to Switzerland or Israel - or even to the U.S. Federal Reserve Board, for its quantitative easing.) See David Parkinson, "Romney's View Aside, China Is No Currency Manipulator" The [Toronto] Globe \& Mail B10 (Nov. 5, 2012).

${ }_{111}^{11}$ Rosa Lastra, Legal Foundations of International Monetary Stability 401 (2006).

${ }^{112}$ Ibid., p. 402.

${ }^{113}$ Ibid., p. 402.
} 
the first three principles and added the further principle that "[a] member should avoid exchange rate policies that result in external instability." 114

*. Thus, it appears that there is growing awareness of the risk, and the attendant "unfairness" to trading relationships, of trade surpluses that may promote or aggravate international economic instability. This instability was pronounced during the 2000s when China's trade surplus with the U.S. soared due to outsourcing aided by an artificially cheapened Chinese currency. However, leading economists have expressed skepticism that a successful claim could be mounted against China either at the IMF or under WTO rules. Thus, for instance, Robert Staiger and Alan Sykes conclude:

The real effects of China's policies are thus potentially quite complex, are not readily translated into trade-policy equivalents, and are dependent on the time frame over which they are evaluated (because prices are less "sticky" over a longer time frame). Accordingly, we are skeptical about many of the policy responses now under consideration in Washington both on economic and legal grounds. ${ }^{115}$

*. Some commentators appear to assert that China is effectively doing nothing wrong. Thus, Bryan Mercurio and Florence Leung come to the paradoxical conclusion that while it "is almost beyond reasonable doubt" that "the Chinese authorities influence and control the exchange regime ... [yet] China does not violate its international obligations." 116 However, it is hard to accept this position if China's activities contribute to global economic instability.

*. The term "unfair" contained in Art. IV:1(iii) and the wording of balance and equilibrium that run throughout the Articles of Agreement must have some meaning. Simply because they have been accorded none to date does not excuse the IMF from coming to some conclusions about them. Otherwise, they risk being reduced to mere surplusage. Mercurio and Leung's analysis of phases like "unfair comparative advantage" is deficient because it sidesteps any effort to get at a reasonable definition, asserting China's unfettered "right" to set its exchange rate as it pleases. Tacit recognition of this position appears to be the direction that IMF rules are evolving in. Nevertheless, the failure to be any more precise about the concept of "fairness" is an indication of an insufficiently developed 'community'.

\section{Some Concluding Thoughts}

*. I have attempted in this article to put forward a definition of fairness and offer an explanation for its recurrent importance in human and international economic relations that goes beyond what has been provided in existing literature. In short, I have suggested that fairness is synonymous with 'appropriateness'.

*. In international economic law the issue of fairness is most closely associated with appropriate treatment, which again, I have suggested is undertaken to preserve and strengthen relationships. This view coheres with humans' biologic and evolutionary nature, which depends upon relationships to accomplish the increasingly complex tasks that sustain human life. The tremendously sophisticated

\footnotetext{
${ }^{114}$ In 2007 the IMF adopted a new Decision on Bilateral Surveillance over Member's Policies, PIN No. 07/69 (June 21, 2007) which clarifies the concept of exchange rate manipulation. An Annex to the decision makes clear, however, that Art. IV:1(iii) is hard to police because in order for an undervalued exchange rate to be inconsistent with Art. IV it must be shown that: 1. The exchange rate is manipulated through policies actually affecting the rate, 2. These policies are engaged in for the purpose of fundamental misalignment, and 3. The purpose of this misalignment is to increase net exports. Furthermore, any representation made by the member regarding the purpose of its policies will be given the benefit of any reasonable doubt. See Catharina Koops, "Manipulating the WTO? The Possibilities for Challenging Undervalued Currencies under WTO Rules", Amsterdam Center for International Law 2010 Research Paper Series p. 14, manuscript available at www.ssrn.com, abstract 1564093 (2010).

115 Robert Staiger \& Alan Sykes, "Currency Manipulation" and World Trade, manuscript available at www.ssrn.com, abstract 1151942 (June 13, 2008).

${ }^{116}$ Bryan Mercurio \& Celine Leung, "Is China a Currency Manipulator? The Legitimacy of China's Exchange Rate Regime Under the Current International Legal Framework" 43:3 International Lawyer 1257 at 1298 (Fall 2009).
} 
networks of production and consumption that have arisen over the last few decades in the form of global supply and value chains tend to bear my point out.

*. The definition of fairness as "appropriateness" offers a number of advantages. For one, we no longer have to resign ourselves to the fact that "talk about fairness is conceptually muddled." 117 Rather, we can be much clearer about what fairness involves and more aware of its ultimate function as a tool of social cohesion. It is also possible to understand why, for instance, recent protests about the unfairness of existing economic arrangements may have taken place in many countries against a background of uneven economic growth and increasing economic disparity. What is happening in many places is an erosion of community.

*. Fairness considerations are most evident in the law of rights because it is rights-oriented situations that most often express "the individuality of the law". ${ }^{118}$ Individuality is manifested differently in different fields of international economic law and ultimately depends upon the overall 'orientation', or 'pitch', of a particular legal system.

*. We have seen, for instance, how the law of international investment appears to be the paradigm of a rights'-based system, being as it is a legal system which concentrates its attention on the protection of individual investors and their investments. Not surprisingly within this matrix, claims to 'fair and equitable treatment' are of increasing frequency and may, in fact, be one reason why other commentators have often complained about the fragmentary nature of the law is in this field and how it fails to display principled coherence. ${ }^{119}$ In WTO law, by contrast, the law is more obligationoriented and generalized, being keyed in most instances to equality-based obligations. Hence, the "individuality of the law" is more obscure. Nevertheless, attention to individualism arises in preambular references to fairness in the WTO Agreements and in particular WTO rules concerned with fair conduct. Finally, in international monetary law the law is chiefly concerned with safeguarding a country's sovereign right to set its own exchange rate. There, the issue of fairness arises as a concomitant of the obligation to avoid manipulating exchange rates in order to gain an "unfair competitive advantage". The failure to define how an "unfair competitive advantage" is to be determined has so far meant that this particular claim to fairness has not been decided under existing rules of the International Monetary Fund (IMF). Nevertheless, in an increasingly interdependent world, one marked by ever-more intensive economic relationships, competing claims to fairness suggest no right is absolute and IMF rules appear gradually to be evolving in the direction of greater obligation.

*. From the above analysis it becomes possible to represent a theory of fairness within a larger theory of justice as follows:

$$
\text { Justice }=\text { Equality }+ \text { Fairness }
$$

*. However, as we have also seen, this basic relationship is accompanied by a series of key provisos:

$$
\begin{aligned}
& \text { (1) Equality > Fairness } \\
& \text { (2) Equality } \neq \text { Fairness } \\
& \text { (3) Equality } \neq \text { Identity }
\end{aligned}
$$

\footnotetext{
${ }^{117}$ Mathias Risse, "Fairness in Trade" 2 (Working Paper, Feb. 5, 2005).

${ }^{118}$ Philip Allott, Eunomia p. 159-160 (II 10.43) (1990).

119 "[M] any critical voices have deplored the lack of predictability and balance of investment arbitration ..." August Reinisch, "The Future of Investment Arbitration" in Christina Binder et al. (eds), International Investment Law for the $21^{\text {st }}$ Century, 894 at 916 (2009).
} 
*. Rules of international economic law reveal a preoccupation with fairness that is roughly consistent with the theoretical view put forward above. Fairness involves "the justice of particular situations". It is therefore no surprise that particular relationships between economic actors (e.g. the WTO membership), between specific countries (e.g. the U.S. and China), between groups of countries (e.g. developing and developed) or between institutions and litigants (e.g. investment tribunals and claimants) should raise fairness claims in international economic law. It is here that the "individuality of the law" is most clearly and forcefully apparent.

*. I have labelled fairness in this article 'appropriateness', or "the justice of the particular". In closing it bears thinking about this definition in connection with the Occupy Movement mentioned in passing at the outset. As mentioned, Occupy's chief claim is with respect to the fairness (or unfairness) of existing social arrangements in many countries, and in particular, growing income in equality. In this connection, we can ask how a "justice of the particular" can be applied to a condition of growing income disparity that is society-wide. Isn't this, in some sense, a mismatch?

*. In answering this question it is important to remember that fairness is a property of relationships. The idea that motivates so much concern today, and that has sparked protests under the banner of Occupy, involves the relationship of individuals to the community at large. Since the Second World War this relationship has been conceived of as one which allows, if not promises, a degree of social mobility from one generation to the next. That promise is now under threat in many countries as a majority of individuals and families find themselves stagnating in terms of opportunities while a small minority advance. This is where the idea of fairness resonates. What is 'appropriate' is being challenged, with the attendant challenge that this presents to the basic framework of human relations underlying society, or 'community'.

*. A metaphoric description to what is happening might be that fairness is characteristic of parts of a whole, rather than the whole itself. In this sense, the examination above tends to confirm the observation made earlier that fairness would probably make a poor rule for human behaviour in every instance. Our behaviour has adapted to this imperative by evolving towards equality, which remains an aspirational and largely unfinished project in any human community.

*. During the U.S. Civil War Abraham Lincoln recognized this very point when he attempted to reconcile references that "all men are created equal" in the U.S. Declaration of Independence with the actual state of race relations at that time. One of Lincoln's biographers has observed:

When the authors of the Declaration spoke of equality, Lincoln insisted, "they did not mean to assert the obvious untruth, that all were then actually enjoying that equality. .... They meant to set up a standard maxim for free society, which should be familiar to all, revered by all; constantly looked to, constantly laboured for, and even though never perfectly attained, constantly approximated, and thereby constantly spreading and deepening its influence, and augmenting the happiness and value of life to all people of all colours everywhere." 120

Lincoln's response emphasizes the way in which equality is generalized and immanent, yet always incomplete and unfinished. In this respect, it is something that a sustainable community is constantly working towards. Equality will form the basis of the community's political affiliation, but beyond that, it is inequality, with its attendant considerations of fairness, that binds people and countries together. ${ }^{121}$

\footnotetext{
${ }^{120}$ Doris Kearns Goodwin, Team of Rivals 207 (2005).

${ }^{121}$ A polis "is composed of unalike elements," that is to say, of individuals who have many different relations to one another - as man and wife, parent and child, soldier and civilian, ruler and ruled - and who engage in many different occupations, "which enables them to serve as complements to one another, and to attain a higher and better life by the mutual exchange of their different services." There cannot then "be a single excellence common to all the citizens, any more than there can be a single excellence common to the leader
} 
of a dramatic chorus and his assistants ... It is as if you were to turn harmony into mere unison, or to reduce a theme to a single beat." Shirley Robin Letwin, On the History of the Ideal of Law (Noel B. Reynolds ed.) 22 (2005).

Fairness in International Economic Law Draft SSRN.doc 